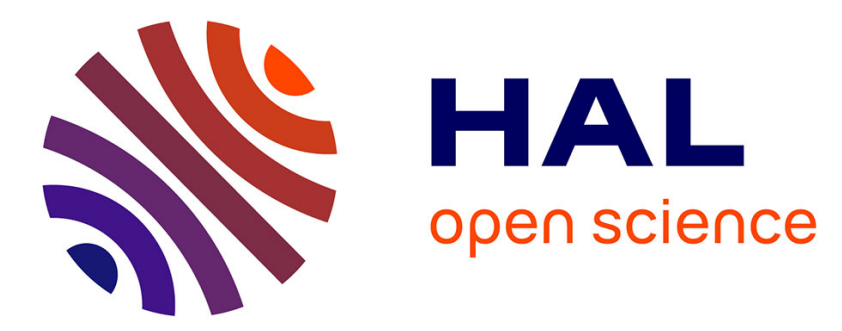

\title{
Early Jurassic climatic trends in the south-Tethyan margin
}

H. Baghli, E. Mattioli, J.E. Spangenberg, M. Bensalah, F. Arnaud-Godet, B. Pittet, G. Suan

\section{> To cite this version:}

H. Baghli, E. Mattioli, J.E. Spangenberg, M. Bensalah, F. Arnaud-Godet, et al.. Early Jurassic climatic trends in the south-Tethyan margin. Gondwana Research, 2020, 77, pp.67 - 81. 10.1016/j.gr.2019.06.016 . hal-03487741

\section{HAL Id: hal-03487741 https://hal.science/hal-03487741}

Submitted on 20 Dec 2021

HAL is a multi-disciplinary open access archive for the deposit and dissemination of scientific research documents, whether they are published or not. The documents may come from teaching and research institutions in France or abroad, or from public or private research centers.
L'archive ouverte pluridisciplinaire HAL, est destinée au dépôt et à la diffusion de documents scientifiques de niveau recherche, publiés ou non, émanant des établissements d'enseignement et de recherche français ou étrangers, des laboratoires publics ou privés.

\section{(ㄷ)(1) $\$$}

Distributed under a Creative Commons Attribution - NonCommercial| 4.0 International 


\section{Early Jurassic climatic trends in the south-Tethyan margin}

2

3 Baghli, H. ${ }^{1,2}$, Mattioli, E. ${ }^{1,3}$, Spangenberg, J.E. ${ }^{4}$, Bensalah, M. ${ }^{2}$, Arnaud-Godet, F. ${ }^{1}$, 4 Pittet, B. ${ }^{1}$, Suan, G. ${ }^{1}$

${ }^{1}$ Université de Lyon, UCBL, ENSL, CNRS, LGL-TPE, 69622 Villeurbanne, France.

2 Laboratoire de Recherche $n^{\circ} 25$, Université de Tlemcen, Algeria.

3 Institut Universitaire de France, Paris, France.

4 Institute of Earth Surface Dynamics (IDYST), University of Lausanne, Building Géopolis, CH-1015 Lausanne, Switzerland.

\section{Abstract}

The Early Jurassic period was characterized by extreme environmental changes, as reflected by major global carbon isotope anomalies and abrupt changes in oxygen isotope and elemental records of marine organisms. Available data suggest an overall warm Early Jurassic climate interrupted by periods of severe cooling, with a climatic optimum during the early Toarcian. Available geochemical studies, however, have mainly focused on the northern margin of the Tethys Ocean, so that the palaeogeographic extent of these environmental perturbations, latitudinal palaeotemperature gradients and climate belt boundaries remain poorly constrained. Here we report the first stable isotope records of brachiopod shells $\left(\delta^{13} \mathrm{C}\right.$ and $\delta^{18} \mathrm{O}$ values) from the Upper Sinemurian-Middle Toarcian interval in the southern margin of the Tethys Ocean (northwest Algeria). These data were used to better constrain the palaeoenvironmental evolution of the North Gondwana margin during the Early Jurassic, which likely played an important role on supra-regional climate. The diagenetic history of the analysed brachiopod shells was monitored using scanning electron microscopy, and elemental (manganese and strontium) compositions. The brachiopod $\delta^{13} \mathrm{C}$ and $\delta^{18} \mathrm{O}$ data show very similar trends as those reported for various Tethyan regions, and record negative carbon and oxygen isotope excursions near the Sinemurian-Pliensbachian and Pliensbachian-Toarcian transitions and during the Toarcian oceanic anoxic event (T-OAE). Despite these similarities, the carbon and oxygen isotope records are systematically offset towards more positive $\delta^{13} \mathrm{C}$ values 
(average $+0.5 \%$ ) and more negative $\delta^{18} \mathrm{O}$ values $(-1.0 \%$ ) compared to those obtained from sites of higher palaeolatitudes in the northern Tethyan margin. These offsets suggest a spatial heterogeneity in the stable isotope composition of dissolved inorganic carbon in the Early Jurassic Ocean and a marked latitudinal temperature gradient between the southern and northern margins of the Tethys.

Keywords: Carbon and Oxygen stable isotopes, Early Jurassic, NW Algeria, Palaeoclimate

\section{Introduction}

The Early Jurassic period ( 200-175 Ma) has been intensively studied because it was a key time interval for the environmental evolution of the western Tethys. Indeed, this time interval is characterized by extreme climate fluctuations, with possible glacial interludes occurring within an interval of general greenhouse conditions (Price, 1999). This interval is marked by major events in the large igneous provinces of the Central Atlantic and Karoo-Ferrar (e.g., Wignall, 2001), and the gradual disintegration of the Pangea supercontinent (Olsen, 1997). Severe perturbations of the carbon cycle are reflected by large fluctuations of the stable carbon isotope composition $\left(\delta^{13} \mathrm{C}\right)$ of marine and terrestrial material. Severe biotic crises, such as the first-order extinction of the end-Triassic (Wignall, 2001) or the Toarcian oceanic anoxic event (T-OAE; Jenkyns, 1988) produced marked floral and faunal turnovers (Harries and Little, 1999; Macchioni and Cecca, 2002; Mattioli et al., 2008; Suan et al., 2008a, 2010).

Numerous studies have focused on the palaeoenvironmental and biological perturbations in sites from the northwestern Tethys (e.g., Harries and Little, 1999; Hesselbo et al., 2000a; Jenkyns et al., 2002; Gomez et al. 2008; Harazim et al., 2013; Ruebsam et al., 2018). However, climate conditions during the Early Jurassic in the Tethyan southern margin are very poorly known (Bodin et al., 2010, 2016; Reolid et al., 2012; Krencker et al., 2014; Ait-ltto et al., 2017). The North Gondwana is considered to be characterized by a more arid climate with respect to the NW Tethys (Aberhan, 2001; van de Schootbrugge et al., 2005). The carbon and oxygen isotope trends have been documented for bulk carbonate, belemnites and brachiopods from uppermost Pliensbachian and Toarcian strata of Morocco (Bodin et al., 2010; Krencker et al., 2014; Ait-ltto et al., 2017). High-resolution carbon isotope records of bulk 
carbonate and associated organic matter in micrite samples from the upper Pliensbachian and lower Toarcian intervals in three sections from the Central High Atlas Basin in Morocco were presented and discussed by Bodin et al. (2016). Apart from these records, there is a desperate lack of information about the climate and environmental evolution in North Gondwana during most of the Early Jurassic interval. The distribution of climate belts and the role played by North Africa in Early Jurassic climate evolution remain therefore poorly understood.

This study presents new carbon and oxygen isotope measurements of brachiopod shell calcite from sections in NW Algeria, which was a marginal part of the NW Gondwana. The data set spans the Early Jurassic interval, from the Upper Sinemurian to the Middle Toarcian. Well-preserved articulate brachiopod shells are considered as some of the most pertinent materials for geochemical analyses, as modern representatives are strictly sessile and benthic organisms that precipitate their calcite shell in close chemical and isotopic equilibrium with ambient seawater (e.g., Veizer et al., 1999). Therefore, their stable isotope record can safely be interpreted in terms of temperature and changes in the isotopic composition of the dissolved inorganic carbon (DIC) pool through time. The isotope data obtained in NW Algeria are here compared to the isotopic records from various NW Tethys settings in order to discriminate between local versus global fluctuations of environmental parameters during the early Jurassic.

\section{Geological background}

The samples studied in this paper were collected from five different sites, all located in NW Algeria, which in the Jurassic was part of the south-west part of the western Tethys (Fig. 1A). These sites are separated longitudinally by a distance of a few hundred kilometres, but were approximately situated at the same palaeolatitude (Fig. 1). Most of the brachiopod samples come from the Alméras collection (Almeras et al., 2007), hosted in the Collections de Géologie de Lyon. These specimens are stratigraphically well-constrained at the ammonite Zone to Subzone level, and come from 22 sections in the Traras, Rhar Roubane, Saïda, Ouarsenis and Nador Mountains (Fig. 1B). These regions are part of the Tello-Rifain chains, which constitute the western Mediterranean part of the Alpine chain and are separated from the Sahara craton by a narrow, tectonic corridor extending eastwards from Morocco (Agadir) to Tunisia (Gabes; Wildi, 1983). 
102 Within the Tlemcen Domain, the Traras Mountains are bounded to the north by the 103 Mediterranean Sea, to the east by the Mio-Pliocene and Quaternary basin of Tafna, to 104 the west by the Beni Snassen Massifs (Eastern Morocco), and to the south by the 105 Maghnia depression. The Traras mountains are subdivided into at least three 106 subbasins (or "umbilici") separated by structural highs in the Early Jurassic (Ameur, 107 1999; Elmi et al., 2006). The slope-basin transition occurred in the eastern Traras 108 Mountains (Benhamou, 1983) (Fig. 1B).

109 A field mission was realized in 2017 in the Mellala section (Traras Mountains) to collect brachiopod specimens from the Pliensbachian-Toarcian transition where brachiopod specimens were scarce in the Alméras collection (Table 1). This section exposes an exceptionally thick ( $50 \mathrm{~m})$ succession of interbedded argillaceous limestones and calcareous marls that are well-constrained biostratigraphically by assemblages of ammonites, brachiopods (Elmi et al., 2006), and calcareous nannofossils (Baghli et al., in prep.).

116 The Rhar Roubane mountains are limited to the north by the Maghnia Plain, to the south by the Oran High Plains, to the east by the Tlemcen Mountains, and to the west by the Oujda Mountains. The Lower Jurassic facies associations are representative of protected carbonate ramp, slope and basin depositional environments (Mekahli, 1988)

120 (Fig. 1B).

121 The Saïda Mountains are located in an intermediate region comprised between the

122 Tell to the north, the Oran High Plains to the south, to the west by the transform fault 123 of Ain-Sefra, and to the east by the high-plains of Sersou. Facies associations in Saïda Mountains are representative of deep-external platform environments, in contrast to the Traras Mountains and to the Rhar Roubane area, which represent shallower, more proximal environments. It was part of a protected transitional zone during most of the

127 Early Jurassic, which opened towards the marine domain in the latest part of the middle 128 Toarcian substage (Elmi and Almeras, 1984; Elmi et al., 1985).

129 In the southern part of the Tell, the Ouarsenis massif is bounded to the north by the 130 Chelif valley, to the south by the Sersou plateau, to the west by the Beni-Chougrane and Mina Mountains, and to the east by the Bibans. During the Early Jurassic, this region corresponded to an internal platform evolving into an external platform, 133 connected to the open sea and showing a deepening trend (Benhamou et al., 2000).

134 The Nador Mountains correspond to a SW-NE alignment of the reliefs located along 135 the southern edge of the Sersou plateau. The Djebel Nador constitutes an intermediate 
136 zone between the Tellian area to the north and the high-plains to the southwest,

137 resulting from the collapse of a Sinemurian-Pliensbachian carbonate platform.

138 Sedimentation in this area indicates a neritic environment to the west and an epi-

139 oceanic environment to the east.

\section{Materials and methods}

\subsection{Brachiopod shell material and preparation}

A total of 156 brachiopod shells from NW Algeria, ranging in age from the upper Sinemurian to the middle Toarcian, were analysed for their carbon and oxygen isotope composition. The isotopic data were obtained from a composite of different articulate brachiopod taxa, including Rhynchonellida (Homoeorhynchia, Soaresirhynchia; Table 1) and Terebratulida (Telothyris, Lobothyris; Table 1). The sediment matrix was mechanically removed from brachiopod specimens using stainless dental tools, and the shell surface was thoroughly washed with deionized water in an ultrasonic bath (three times for 10-min with renewed water), rinsed with $\mathrm{MQ}$ water (obtained from a Direct-Q Millipore ${ }^{\circledR}$ purification system), and dried at $50^{\circ} \mathrm{C}$ for $48 \mathrm{~h}$. The outermost layer

154 of the brachiopod shells was carefully removed with a dental tool under a 155 Stereomicroscope (Leica M125) at $80 \mathrm{X}$. Powders for stable isotope measurements were obtained by scraping the pristine long and thin fibrous textures lying in the innermost secondary layer of the anterior shell (Fig. 2).

\subsection{Analyses}

The preservation of calcite fibres of all brachiopod shells was assessed under the optical microscope and scanning electron microscope (SEM) using a PHENOM G2

163 PRO instrument in backscatter mode (Phenom-World B.V., Dillenburgstraat 9T, 5652

164 AM, Eindhoven, The Netherlands) before stable isotope measurements.

165 The carbon and oxygen isotope measurements were performed using a Thermo Fisher 166 Scientific (Bremen, Germany) Gas Bench II carbonate preparation device, connected 167 to a Delta Plus XL isotope ratio mass spectrometer at the Institute of Earth Surface 168 Dynamics of the University of Lausanne. The $\mathrm{CO}_{2}$ extraction was done by reaction of 100-200 $\mu \mathrm{g}$ of powdered carbonate sample with anhydrous phosphoric acid at $70^{\circ} \mathrm{C}$. 
170 The carbon and oxygen isotope ratios are reported in the delta $(\delta)$ notation as the per 171 mil (\%o) deviation relative to the Vienna Pee Dee belemnite standard (VPDB). The 172 standardization of the $\delta^{13} \mathrm{C}$ and $\delta^{18} \mathrm{O}$ values relative to VPDB was done by replicate 173 analysis of the in-house working standard Carrara marble (UNIL-CM, $\delta^{13} \mathrm{C}=2.05 \%$, $174 \delta^{18} \mathrm{O}=-1.70 \%$ ) within the analytical sequences. The $\delta^{13} \mathrm{C}$ and $\delta^{18} \mathrm{O}$ values of the 175 reference $\mathrm{CO}_{2}$ gas and the UNIL-CM standard were obtained by normalization with the 176 international reference materials NBS-19 limestone, NBS-18 carbonatite and LSVEC 177 lithium carbonate using the values reported in Brand et al. (2014). Analytical uncertainty $(1 \sigma)$, monitored by replicate analyses of NBS-19 and UNIL-CM was not greater than $\pm 0.05 \%$ for $\delta^{13} \mathrm{C}$ and $\pm 0.1 \%$ for $\delta^{18} \mathrm{O}$.

180 Trace element analysis was performed at the Laboratoire de Géologie de Lyon, on the fibrous secondary layer of selected brachiopods. A total of 57 specimens were selected for element analysis, including those sample that had apparently anomalous $\delta^{13} \mathrm{C}$ and $\delta^{18} \mathrm{O}$ values, and also some samples with isotopic ratios in the range of marine carbonates. For each brachiopod specimen, $1 \mathrm{mg}$ of powdered sample was digested in $10 \mathrm{ml}$ of $\mathrm{HNO}_{3}$ solution ( $\left.5 \% \mathrm{v} / \mathrm{v}\right)$ for $24 \mathrm{~h}$. An aliquot of $1 \mathrm{ml}$ from each stock solution was then diluted in a solution of $9 \mathrm{ml}$ of $\mathrm{HNO}_{3}(2 \% \mathrm{v} / \mathrm{v})$ and Indium $(2 \mu \mathrm{g} / \mathrm{l})$. Each solution was analysed for $\mathrm{Sr}$ and $\mathrm{Mn}$ by an inductively plasma mass spectrometer (ICP MS), Agilen Technologies 7500 Series.

189

\subsection{Data treatment}

191

192 A numerical age was attributed to each analysed brachiopod, based on available stratigraphic information (i.e., ammonite zone and subzone). The ages of each biozone were derived from the timescale of Gradstein et al., (2012). The stable isotope data $\left(\delta^{13} \mathrm{C}\right.$ and $\delta^{18} \mathrm{O}$ values) were smoothed to better highlight the long-term trends. Two methods for smoothing data by locally weighted regression were implemented, the LOESS smoothing function using the software PAST 3.18 (Hammer et al., 2001), and

198 the lowess algorithm (Cleveland, 1981). Lowess is a linear polynomial smoother, whereas the LOESS procedure uses a quadratic polynomial to avoid over-fitting and excessive twisting and bending (e.g., Faber and Rajko, 2007). The smoothing factor applied to the whole data is 0.1 . Such a small factor was chosen in order to highlight short-term fluctuations in the considered time interval. 
The LOESS smoothing with a factor of 0.1 was also applied to the data available in the

204 literature from different Tethyan regions. For each region, the smoothed isotopic data were computed, plotted against absolute age, and compared to the LOESS values obtained for NW Algeria. One-way ANOVA analyses were used to determine the significance (probability value $P$ ) of the observed differences (offsets). The difference between two groups is considered to be statically significant at the $95 \%$ level when $P$ $209 \leq 0.05$.

\section{Results}

\subsection{Optical microscopy and SEM images}

All the brachiopod specimens were screened under SEM and optical microscope before $\mathrm{C}$ and $\mathrm{O}$ isotope analyses. The textures observed vary from well-preserved, when calcite fibres are long and thin, without any clear trace of overgrowth (Fig. 2C), to mediumly-preserved material showing slightly overgrown fibres (Fig. 2B). Few brachiopod specimens have shown very poorly preserved calcite fibres, almost completely overgrown. The ultra-structure of the inner layers of the shell of all the brachiopod under SEM (Fig. 2) allowed us to discard specimens showing a variable but strong degree of post-depositional alteration that resulted in marked textural changes compared to that of modern specimens. These changes are expressed by a loss of pristine microstructures, ranging from slight dissolution of calcite fibres to almost complete obliteration of any fibrous structure (Bates and Brand, 1991). Such specimens were not processed for geochemical analyses. After this screening by optical microscopy and SEM analysis, 156 brachiopod shells were retained for $\delta^{13} \mathrm{C}$ and $\delta^{18} \mathrm{O}$ measurements.

\subsection{Carbon and oxygen isotope data and trace element concentrations}

232 The $\delta^{13} \mathrm{C}$ and $\delta^{18} \mathrm{O}$ values of well-preserved brachiopod shells are given in Appendix 233 A (Supplementary data). The $\delta^{13} \mathrm{C}-\delta^{18} \mathrm{O}$ scatterplot shows a large dispersion of data 234 (Fig. 4), with $\delta^{13} \mathrm{C}$ values ranging from 0 to $5.0 \%$ and $\delta^{18} \mathrm{O}$ values from -5.0 to -1.0 $235 \%$. Few samples record anomalously negative $\delta^{13} \mathrm{C}$ (down to $-4.8 \%$ ) and $\delta^{18} \mathrm{O}$ (down 
236 to $-7.6 \%$ ) compared to the Mesozoic and modern brachiopod records, which are 237 strongly suggestive of strong post-mortem diagenetic overprint. No clear $\delta^{13} \mathrm{C}-\delta^{18} \mathrm{O}$ 238 relationship was observed for $95 \%$ of the brachiopod specimens, even when 239 considering the different localities separately (Fig. 4). The relative stratigraphic position 240 of brachiopods in the different sections was respected and vertical bars on the isotope 241 curves (Fig. 5) indicate the stratigraphic extension of brachiopod ages according to 242 ammonite zones and sub-zones. The main differences in the isotopic composition of 243 the brachiopod shells occur between localities and are likely due to the record of various time spans in the different study areas (Appendix B). Nonetheless, the relatively large variability of the composite specimen samples is certainly attributable to the presence of peculiar environmental conditions in a given area or to different water-depths that likely affect the isotope results (Fig. 5). The $\delta^{13} \mathrm{C}$ trends reveal several events across the studied interval, which are more clearly visible in the LOESS smoothing curve (Fig. 5). The earliest event is recorded at the Sinemurian/Pliensbachian boundary, where a pronounced $\sim 2.5 \%$ negative excursion, with $\delta^{13} \mathrm{C}$ values as low as $-4.0 \%$ mark the Raricostatum-Jamesoni interval. According to the original study of Alméras et al. (2007), the analysed brachiopods belong to an assemblage characteristic of the Sinemurian/Pliensbachian boundary. Importantly, the samples showing positive values were collected in the lower part of the section, the brachiopods showing negative values were collected in the upper part of the same section (see Supplementary material). In the lbex zone and in the lower part of the Davoei zone, $\delta^{13} \mathrm{C}$ values are around $1.0 \%$. In the upper part of the Davoei zone, more positive values reach up to $4.0 \%$. The $\delta^{13} \mathrm{C}$ values return close to $\sim 1.0 \%$ near the transition between the Lavinianum-Algovianum Zones, and show a $\sim 1.0 \%$ negative excursion in the uppermost Pliensbachian (Emaciatum Zone). Towards the lowermost part of Tenuicostatum zone, the $\delta^{13} \mathrm{C}$ values become more positive with a $+2.0 \%$ shift, and decrease upwards to $-1.0 \%$ in the basal part of the Serpentinum Zone. After this event, a large shift toward positive values (up to $4.5 \%$ ) characterizes the middle part of the Serpentinum zone, followed by some less pronounced fluctuations until the Bifrons zone with an average value of $3.0 \%$. At the Sinemurian/Pliensbachian boundary, the $\delta^{18} \mathrm{O}$ values range between $-5.2 \%$ and $-3.0 \%$ (on average $-4.3 \pm 0.68 \%$ ). The $\delta^{18} \mathrm{O}$ values increase considerably in the Ibex zone (lower Pliensbachian) and at the base of the Davoei zone, both with average 
270 to an average of $-4.0 \%$. Up to the beginning of the Emaciatum zone, the oxygen271 isotope values are rather stable with an average at $-3.0 \%$. Passing from the 272 Emaciatum zone to the Pliensbachian/Toarcian boundary, the $\delta^{18} \mathrm{O}$ values record a 273 negative excursion of almost $2.0 \%$ attaining an average of $-4.0 \%$ at the boundary. A 274 positive $2.0 \%$ shift characterizes the base of the Toarcian with average values of -2.0 $275 \%$ towards the middle part of the Tenuicostatum zone. This isotopic change is followed 276 by a second negative excursion ending in the lower part of the Serpentinum zone, with 277 average $\delta^{18} \mathrm{O}$ values of $-3.8 \%$. In the aftermath, small isotopic rebounds to less 278 negative values (of $\sim 0.8 \%$ ) are recorded, after which $\delta^{18} \mathrm{O}$ values, although fluctuating, 279 enter a $\sim 2.0 \%$ long term trend toward more negative values extending from the middle 280 part of the Serpentinum zone to the middle part of the Bifrons zone and lasting around 2812 Myrs.

282 The trace element contents of the selected samples revealed $\mathrm{Sr}$ contents varying 283 between 130 and 1000 ppm, with most samples exceeding 450 ppm (on average 524 $284 \pm 260$ ) (Fig. 3). Mn contents range between 3 to about 80 ppm (on average $64 \pm 58$ ). 285 Half a dozen samples are depleted in $\mathrm{Sr}$ and enriched in $\mathrm{Mn}$ (Supplementary data).

286 Ten samples show anomalously negative $\delta^{13} \mathrm{C}$ and $\delta^{18} \mathrm{O}$ values, or anomalous 287 contents in both $\mathrm{Mn}(<80 \mathrm{ppm})$ and $\mathrm{Sr}$ ( $>450 \mathrm{ppm}$ ) with respect to modern brachiopod 288 shells secreted in equilibrium with ambient water (e.g., Brand and Veizer, 1980; Brand 289 et al., 2003). These samples were hence excluded from the LOESS calculation, but 290 are presented in the chemostratigraphic profiles in Figures 5 to 7.

291 The comparison of LOESS smoothing data from NW Algeria and from different 292 Tethyan regions shows an offset of $1 \%$, which, according to the one-way ANOVA 293 analyses, is statistically significant $(P=1 \mathrm{E}-05$; permutation $\mathrm{n}=99999)$.

\section{Discussion}

A certain degree of variability is observed both for carbon and oxygen isotopes (Fig. 5). Such variability is higher than that observed by Suan et al. (2010) in brachiopods of comparable age from the Portuguese Peniche section in Portugal. However, this can be partly due to the different environmental origin of the brachiopods sampled in five different regions of the NW Algeria. The water depth differences between the studied regions in Algeria are not important, as samples belong to outer platform, slope or shallow-basin settings. Furthermore, these five regions were located almost at the 
same palaeolatitude. Thus, apart from the data dispersion (Fig. 5) also reported from brachiopod isotope composition in other time intervals (e.g., Giraud et al., 2016), some prominent excursions are observed in the present work for $\delta^{13} \mathrm{C}$ and $\delta^{18} \mathrm{O}$ values from NW Algeria (i.e., Sinemurian-Pliensbachian boundary, Pliensbachian-Toarcian boundary, early Toarcian Anoxic Event). These excursions can likely be related to palaeoclimatic and palaeoceanographic events, once proven the primary nature of the isotopic signal. The palaeoenvironmental significance and interpretations of these isotopic records can then be safely compared with analogous records from other Tethys regions.

\subsection{Preservation of brachiopods shells}

Present-day articulate brachiopods (Rhynchonellida, Terebratulida) are strictly benthic and sessile organisms that generally precipitate their secondary shell layer in isotopic equilibrium with the ambient waters (Brand et al., 2003; Brand et al., 2013), and incorporate trace elements and stable isotopes from the surrounding environments (Brand and Veizer, 1980). In the case of exposure of this carbonate phase to meteoric waters, it might undergo partial or total dissolution, exchange trace elements and stable isotopes with those of interstitial water, and finally re-precipitate as diagenetic calcite (Brand and Veizer, 1980). In modern brachiopod species, the outermost primary layer, which is characterized by a thickness of about $50 \mu \mathrm{m}$ and a granular texture, is most probably secreted out of isotopic equilibrium with sea water (Carpenter and Lohmann, 1995; Auclair et al., 2003; Brand et al., 2003). Specialized structures (mainly located in the posterior part of the shell) and the uppermost part of the secondary shell were excluded from analysis as, in modern brachiopod species, these parts may also have an isotope signature out of the expected values for calcite precipitated in isotopic equilibrium with environmental water (Carpenter and Lohmann, 1995; Curry and Fallick, 2002; Auclair et al., 2003). The stable isotope analyses were performed on powders obtained from the outermost layer of the brachiopod shells (see section 3.1). SEM images were used to evaluate the preservation of the microstructures of the secondary layer, the shell microstructures are considered to be well preserved when smooth fibrous surfaces of secondary layer occur, similarly to those observed in living specimens (Brand et al., 2003; Suan et al., 2008a). Diagenetically-altered structures of the secondary layer of brachiopod shells are identified by the poor individualization 
of calcite fibres (Suan et al., 2008a; Giraud et al., 2016). In specimens showing a good preservation of the calcite fibres of the secondary layer under SEM, the primary character of the stable carbon and oxygen isotope composition of the brachiopod shells was tested using the concentrations of strontium and manganese, which are known to be sensitive to diagenetic alteration (Brand and Veizer, 1980; Brand et al., 2003). Although it has been shown that there were variations in the concentrations of these elements through the Phanerozoic in relation with episodes of aragonite and calcite seas (Steuber and Veizer, 2002), it is widely acknowledged that the Sr concentration of low-magnesium calcite in the well-preserved secondary brachiopod layer varies between 450 and 1900 ppm at middle-to-low latitudes, while Mn values vary between 0 ppm and about 80 ppm (Brand and Veizer, 1980; Korte et al., 2003), even in modern brachiopods (Brand et al., 2003).

The Sr and Mn contents of almost all the brachiopod shells are in the range of unaltered fossil brachiopod calcite mentioned above, with the exception of few specimens that are plotted with different symbols along non-altered samples in figure 3, but excluded from our isotopic interpretations and thus not discussed in the following. In some cases, the anomaly only concerns a single trace element (i.e., Mn or Sr), and the $\delta^{13} \mathrm{C}$ and $\delta^{18} \mathrm{O}$ values are well within those expected for primary marine carbonates. Mn contents outside the range for low-Mg calcite are probably due to seasonal conditions that may influence the Mn contents of sea-water, with a decrease in winter and an increase in spring (Dromgoole and Walter, 1990). Alternatively, redox conditions may also affect the trace element concentrations (Vander Putten et al., 2000). The Sr content in calcite of modern bivalve species appears to be greatly controlled by kinetic and metabolic effects (Freitas et al., 2005; Vander Putten et al., 2000), a possible minor temperature and salinity influence may occur (Beck et al., 1992; Elderfield and Ganssen, 2000). In the brachiopods we analysed, no difference in $\mathrm{Sr}$ and $\mathrm{Mn}$ concentrations between specimens and species from the same stratigraphic level were observed. Our results show that the $\mathrm{Mn}$ content is similar between two analysed genera and varying $\mathrm{Sr}$ contents between genera, if any, could probably reflect particular metabolic effects (Table 1).

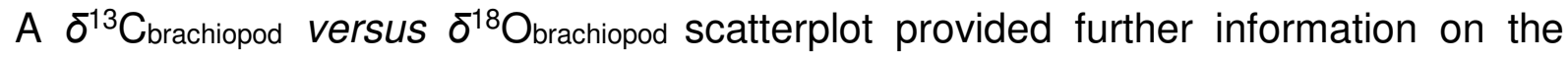
eventual diagenetic modification by meteoric waters (Fig. 4). A 95\% ellipse data concentration shows that most of the values obtained in this paper are in the range of "normal" marine carbonates. Sedimentary diagenesis involves recrystallization 
372 (dissolution and precipitation) and/or overgrowth on primary carbonate minerals, 373 resulting in a depletion in ${ }^{13} \mathrm{C}$ and ${ }^{18} \mathrm{O}$ of the secondary carbonate phases (Burdett et 374 al., 1990; Bates and Brand, 1991; McConnaughey et al., 1997; Auclair et al., 2003), 375 and therefore generating a positive linear $\delta^{13} \mathrm{C}-\delta^{18} \mathrm{O}$ correlation. The large dispersion 376 of our results in the $\delta^{13} \mathrm{C}-\delta^{18} \mathrm{O}$ scatterplot and the absence of clear correlation between 377 values suggest that the isotopic composition of brachiopod shells did not suffered 378 major diagenetic overprint. However, the $\delta^{13} \mathrm{C}$ and $\delta^{18} \mathrm{O}$ values of samples from the 379 different localities seem to form distinct clusters (Fig. 4). This is mainly related to the 380 fact that the studied localities correspond to different stratigraphic intervals, recording 381 382 distinct temporal changes of the $\delta^{13} \mathrm{C}$ and $\delta^{18} \mathrm{O}$ values. Conversely, the differences in isotopic compositions between genera, species or specimens sampled within a given stratigraphic level are relatively small, ranging from 0 to about $1 \%$ for both $\delta^{13} \mathrm{C}$ and $\delta^{18} \mathrm{O}$ values (Table 1 ), in line with the inter-specimen variability of modern brachiopod or bivalve specimens collected from the same localities (Carpenter and Lohmann (1995) and Vander Putten et al. (2000).

\subsection{Late Sinemurian - Early Pliensbachian interval}

In spite of the broad stratigraphic range of the brachiopod specimens analysed in this study that have been assigned to the Raricostatum to Jamesoni zones, the new data from NW Algeria sites show a prominent negative carbon isotope excursion (CIE) and a $1.0 \%$ negative shift in oxygen isotopes that might correspond to the Sinemurian/Pliensbachian interval. Previous studies have shown that the negative CIE at the Sinemurian/Pliensbachian interval has a supra-regional nature (Figs. 6 and 7). The CIE is recorded in Spain (Rosales et., 2006), Portugal (Suan et al., 2010; Duarte et al., 2014), and the UK (Jenkyns et al., 2002; Korte and Hesselbo, 2011; Price et al., 2016). Some authors interpreted this negative $\delta^{13} \mathrm{C}$ excursion as reflecting the massive injection of isotopically light carbon into the ocean-atmosphere reservoirs (Korte and Hesselbo, 2011; Price et al., 2016). Several sources have been proposed for similar events recorded in the Phanerozoic, such as methane release from clathrates, wetlands, thermal metamorphism, kerogen maturation, or decomposition of fossil organic matter (e.g., Scholle and Arthur, 1980; Dickens et al., 1995; Kump and Arthur, 1999; Higgins and Schrag, 2006). However, it is unclear which of these mechanisms 
case of NW Algeria, and in several other cases, the negative CIE at the 407 Sinemurian/Pliensbachian boundary appear to be as a sharp $\delta^{13} \mathrm{C}$-excursion. This can be explained either by the presence of a sedimentary condensation or a hiatus, or by the occurrence of a sudden event. The second hypothesis is the most plausible, considering the abruptness of the $\delta^{13} \mathrm{C}$ decrease in several localities, such as in the stratotype for the base of the Pliensbachian (Robin Hood's Bay, NE England), which is known to be only slightly or not affected by condensation or hiatuses (Hesselbo et al., 2000b).

Oxygen isotope data can help understanding the perturbations of the carbon cycle across the Sinemurian/Pliensbachian transition. The variations in the $\delta^{18} \mathrm{O}$ values of the brachiopod shell reflect mainly changes in ambient temperature and seawater oxygen isotope composition, which indirectly reflect changes in salinity (Brand et al., 2013). The oxygen isotope fractionation between calcite and water is temperature dependent, and warmer waters lead to ${ }^{18} \mathrm{O}$ depleted calcite (Lowenstam, 1961; O'Neil et al, 1969). Although a certain dispersion is observed in Upper Sinemurian-Lower Pliensbachian $\delta^{18} \mathrm{O}$ values, a trend to more negative $\delta^{18} \mathrm{O}$ values in the brachiopod shells is observed. This trend has revealed to be statistically significant after an ANOVA test and most probably indicates a sudden temperature increase. This temperature increase would support the hypothesis of a massive injection of isotopically light carbon in the ocean-atmosphere system, because enhanced emissions of $\mathrm{CO}_{2}$ and $\mathrm{CH}_{4}$ might have produced an increased greenhouse effect. Furthermore, the oxygen isotope data of the studied areas do not show more positive $\delta^{18} \mathrm{O}$ values than the northern localities, as it would be expected in case of higher seawater salinity (Epstein and Mayeda, 1953). High evaporation rates should have occurred in NW Algeria, which occupied the southern Tethys arid margin during the

431 Early Jurassic (Turner and Sherif, 2007). A positive $\delta^{18} \mathrm{O}$ shift is conversely reported across the Sinemurian-Plienbachian boundary (Korte and Hesselbo, 2011). However, this shift is likely produced by a bottom water cooling related to a deepening phase in the Cleveland Basin (Korte and Hesselbo, 2011). This cooling might be the expression of local conditions rather than a climatic deterioration. In the Davoei zone, another isotope event is recognized despite the relatively low data resolution in this interval. The $\delta^{13} \mathrm{C}$ values in the NW Algeria sections show a positive excursion similar to that observed in other regions (Silva et al., 2011; Franceschi et al., 
440 phenomenon; it is also marked by a drop in the ammonite species richness in the 441 Mediterranean and NW European provinces (Dommergues et al., 2009). At the Davoei 442 zone, also a prominent negative $\delta^{18} \mathrm{O}$-excursion indicates warmer conditions (Fig. 5).

443 This event was a relatively hot, humid phase, as shown in NW European sediments by 444 kaolinite enrichment and a high ${ }^{87} \mathrm{Sr} /{ }^{86} \mathrm{Sr}$ values caused by enhanced continental 445 weathering (Jones and Jenkyns, 2001; Dera et al., 2009).

\subsection{Late Pliensbachian - Early Toarcian interval}

In the Late Pliensbachian, the $\delta^{13} \mathrm{C}$ values settle between 1 and $2 \%$ in the LavinianumAlgovianum zones (time equivalent of the Margaritatus zone of the Boreal Realm). This trend has been reported in coeval strata from several localities in Europe (Jenkyns and Clayton, 1986; Bailey et al., 2003; Rosales et al., 2006; Suan et al., 2010; Korte and Hesselbo, 2011), and is accompanied in some sections, as those in Portugal and Spain by the occurrence of black shales in the Margaritatus Ammonite Zone (Rosales et al., 2006; Suan et al., 2010; Silva et al., 2015). A trend towards higher $\delta^{18} \mathrm{O}$ values in the Late Pliensbachian (Fig. 5) most probably indicates a trend to cooler seawater culminating in the Emaciatum (or Spinatum) zone, as it was suggested for similar $\delta^{18} \mathrm{O}$ trends in coeval belemnites and brachiopods from France, Germany, England, Spain or Portugal (e.g., Mcarthur et al., 2000; Rosales et al., 2004a; van de Schootbrugge et al., 2005; Oliveira et al., 2006; Harazim et al., 2013). Several studies have discussed the possible causes of this cooling event. Guex et al. (2001) interpreted this cooling as the result of a decreased insolation following the repeated volcanogenic $\mathrm{SO}_{2}$ emissions in the Karoo-Ferrar Large Igneous Province. Similarly, Jourdan et al. (2008) inferred a temporal correspondence between the earliest pulses of the Karoo-Ferrar LIP and the beginning of the climate cooling in the upper Pliensbachian. However, this interpretation remains speculative given the short-term residence time in the atmosphere of sulphur aerosols ( 10 years) (Wignall, 2001), while the cooling event lasted longer than 1 Myrs according to recent astronomical calibration of Upper Pliensbachian strata from the Mochras borehole in Wales (Ruhl et al., 2016). This cooling episode could also be ascribed to a global drawdown of atmospheric $\mathrm{CO}_{2}$ (inverse greenhouse effect) caused by a widespread burial of isotopically light organic

472 carbon ensuing the accumulation of organic matter-rich sediments in the Margaritatus 
474 Across the Pliensbachian/Toarcian boundary, the negative $\delta^{13} \mathrm{C}$ excursion in Algeria 475 correlates remarkably well with that recorded in coeval sites in NW Europe, which was 476 interpreted as reflecting another pulse of massive injection of ${ }^{13} \mathrm{C}$-depleted carbon into 477 the oceans and the atmosphere (Hesselbo et al., 2007; Suan et al., 2008a). This 478 hypothesis is consistent with the marked $\delta^{18} \mathrm{O}$ negative excursion in biogenic 479 carbonates at the same level in Algeria (Fig. 5), Spain and Portugal (Fig. 7), which has 480 been interpreted in the latter localities as the evidence of a sharp increase in 481 temperature (Suan et al., 2008b) more or less directly linked to a pulse of the activity 482 in the Karoo-Ferrar LIP (Jourdan et al., 2008; Littler et al., 2009; Pálfy and Smith, 2000; 483 Percival et al., 2015, 2016). At the end of this Pliensbachian/Toarcian event, a relatively 484 small positive rebound of $\delta^{13} \mathrm{C}$ values is noticed in almost all the sites in the lower part 485 of the Tenuicostatum Zone (Fig. 6), which correlates with a trend toward higher $\delta^{18} \mathrm{O}$ 486 values (Fig. 7) and can be interpreted as a temporary cooling event.

\subsection{Early-Middle Toarcian environmental evolution}

A marked shift towards lower $\delta^{13} \mathrm{C}$ values is recorded in NW Algeria in the basal Serpentinum zone, followed by a gradual return to higher values. We interpret this shift as the expression of the well-documented negative CIE often used to define the base of the T-OAE interval. Again, this CIE is classically interpreted as being derived from the massive and rapid injection of ${ }^{13} \mathrm{C}$-depleted carbon to the ocean-atmosphere reservoirs, possibly as the result of the release of methane from continental margins (Hesselbo et al., 2000a; 2007; Kemp et al., 2005), of enhanced $\mathrm{CO}_{2}$ emissions during a renewed peak activity of the Karoo-Ferrar LIP (Suan et al., 2008a; Burgess et al., 2015), of thermogenic methane related to the LIP emplacement, or due to the combined effects of all these processes (Beerling and Brentnall, 2007). These hypotheses are consistent with the coeval negative $\delta^{18} \mathrm{O}$ values recorded in NW Algeria (Fig. 5) which, although less intense that observed in in other areas (Fig. 7), suggests warm conditions during the T-OAE (e.g., Suan et al., 2010; Korte and Hesselbo, 2011; Svensen et al., 2007). In the aftermath of the T-OAE, a marked $2.0 \%$ positive $\delta^{13} \mathrm{C}$ excursion at the Serpentinum zone is recorded in NW Algeria as well as in many other localities (e.g., Jenkyns et al., 2002). This positive $\delta^{13} \mathrm{C}$ excursion is considered to reflect the global burial of excess organic carbon, which in turn likely caused a climate cooling through 
$508 \mathrm{CO}_{2}$ drawdown, as an inverse greenhouse effect (e.g., Jenkyns et al., 2002; Hermoso and Pellenard, 2014; Xu et al., 2017). This scenario is supported by the relatively large positive shift toward higher $\delta^{18} \mathrm{O}$ values recorded in the same interval and most likely reflecting a period of cooling (Fig. 7).

\subsection{Differences between $C$ - and O-isotope records from NW Algeria and western}

514 Tethys

The new brachiopod C- and O-isotope profiles show some interesting similarities but also differences with previously published data from different NW Tethys regions based on measurements of belemnite or brachiopod calcite. The possible causes of these differences are discussed in the following sections.

\subsubsection{Trends in $\delta^{13} \mathrm{C}$ values}

The $\delta^{13} \mathrm{C}$ curve of NW Algeria sections shows the main excursions recorded in other European settings, as well as a similar steady trend during the mid-Pliensbachian stage. In particular, the Sinemurian/Pliensbachian negative excursion, the Davoei positive excursion, the Pliensbachian/Toarcian negative excursion, the basal Toarcian positive shift and the Early Toarcian negative excursion are all recorded in NW Algeria. Importantly, the comparison of the different sections shows that the belemnite $\delta^{13} \mathrm{C}$ data from NW Europe are systematically offset towards more negative values than those of North Africa, with an overall offset of $\sim 0.5 \%$ (Fig. 6 ). This offset of the LOESS-smoothed $\delta^{13} \mathrm{C}$ values is statistically significant, and may suggest that the C-isotope composition of the dissolved inorganic carbon (DIC) in shallow shelf waters of the Western Tethys were spatially heterogeneous during the

\section{Early Jurassic.}

535 This offset could be explained by differences in ecology, physiology and modes of life

536 of brachiopods and belemnites. In fact, $\delta^{13} \mathrm{C}$ values of DIC decrease with increasing 537 depth due to the remineralisation of ${ }^{13} \mathrm{C}$-depleted organic matter. The lower $\delta^{13} \mathrm{C}$ 538 values recorded in belemnites suggest that they secreted their calcite rostra in deep waters, more enriched in free ${ }^{13} \mathrm{C}$-depleted DIC (Wierzbowski and Joachimski, 2007;

540 Dutton et al., 2007). Such differences could also explain why belemnite $\delta^{13} \mathrm{C}$ values from Peniche in Portugal (Jenkyns et al., 2002; Hesselbo et al., 2007) are more 
542 negative than those obtained for brachiopods (Suan et al., 2010) from the same site

543 (Fig. 6). The higher amplitude of the $\delta^{13} \mathrm{C}$-excursions measured in NW Europe can be 544 tentatively interpreted as the result of a greater supply of freshwater by rivers to the epi-continental N-Tethyan basins. In fact, the oceanic DIC is fed by freshwaters 546 enriched in oxidized organic matter thus have a ${ }^{13} \mathrm{C}$-depleted DIC. This leads to the 547 precipitation of biogenic carbonates with more negative $\delta^{13} \mathrm{C}$ values (Clayton and 548 Degens, 1959). It has been also suggested that higher productivity at higher latitudes 549 led to a ${ }^{13} \mathrm{C}$ enrichment of the DIC in surface waters (e.g., the Cleveland Basin, 550 Harazim et al., 2013). Episodes of higher productivity in western European sites or transient migrations of belemnites toward higher latitudes may have intensified 552 changes in belemnite $\delta^{13} \mathrm{C}$ records.

553 The tectono-climatic regime of North Africa might also have influenced the C-isotope 554 signals. Following the Triassic rift phase related to the opening of the North Atlantic 555 and of the Neo-Tethys (Favre and Stampfli, 1992), restricted continental basins would 556 have developed under arid climates in the Lower Jurassic northern part of Gondwana 557 (Bracène and Frizon de Lamotte, 2002). High evaporation in such palaeo-lakes would have produced substantial ${ }^{13} \mathrm{C}$ and ${ }^{18} \mathrm{O}$ enrichment as the production of light isotopes is favoured in water vapour. The resulting covariance between $\delta^{18} \mathrm{O}$ and $\delta^{13} \mathrm{C}$ is hence generally considered as an evidence of hydrological closure in palaeo-lakes deposits. Accordingly, in the case of continental runoff of such palaeo-lake basins, the $\delta^{13} \mathrm{C}$ signal in adjacent marine basins should be significantly shifted towards more positive values (Talbot, 1990; Deocampo and Jones, 2014). However, the measured $\delta^{13} \mathrm{C}$ values in NW Algeria sections are in the range of "normal" marine carbonates, and do not show such very positive values. It seems therefore unlikely that the NW Algeria basins have been under the influence of continental runoff from surrounding arid lakes.

\subsubsection{Trends in $\delta^{18} \mathrm{O}$ values}

Although the carbon isotope records in NW Algeria show the main events reported in other Tethys settings, the oxygen isotope data show an important difference. Systematically, the $\delta^{18} \mathrm{O}$ values are 1.5 to $2.0 \%$ lower compared to those from NW

573 Tethys sections (e.g., N Spain, France, England), where isotope data mainly derive from belemnite calcite. The offset of the LOESS-smoothed $\delta^{18} \mathrm{O}$ values is statistically significant. The relatively low $\delta^{18} \mathrm{O}$ values in NW Algeria samples are, however, in the 
same range as those obtained by Krencker et al. (2014) on brachiopods from Toarcian shelf sediments in Morocco. This offset was partly expected, since these two regions were both located at lower palaeo-latitudes, and therefore were likely to have experienced warmer seawater temperatures (i.e., warm subtropical region; Aberhan, 2001 ) than European sites. Interpreting the $\delta^{18} \mathrm{O}$ records solely in terms of temperature and considering available $\delta^{18} \mathrm{O}$-temperature equations (Epstein et al., 1953; Anderson and Arthur, 1983), this 1.5 to $2.0 \%$ offset would suggest that seawater temperatures were about 6 to $8^{\circ} \mathrm{C}$ warmer in Northern Gondwana than in NW Europe, which appears unrealistic for the relatively low palaeo-latitudinal range implied ( $\sim 5$ to $20^{\circ}$; Fig. 1 ). In addition, the high belemnite $\delta^{18} \mathrm{O}$ values recently reported for the Pliensbachian/Toarcian boundary of Issouka in the Central Atlas of Morocco (0 to -1.0 \%o; Aït-ltto et al., 2017) are almost identical to those obtained for most European belemnites of the same interval (Fig. 7). This similarity suggests that there was no difference in seawater temperature between these various areas, an interpretation that is at odds with the new data set.

As discussed above for $\delta^{13} \mathrm{C}$ records (section 4.5.1), however, the difference in material used for geochemical investigations, namely brachiopods in this study versus belemnites in most other published works, may introduce a substantial ecological and physiological bias in the comparison of the $\delta^{18} \mathrm{O}$ records (Ullmann et al., 2016). Indeed, several studies have suggested that belemnites precipitate their calcite in deeper waters than brachiopods. This hypothesis is supported by the $\delta^{18} \mathrm{O}$ record of belemnites from Portugal (Jenkyns et al., 2002; Hesselbo et al., 2007), which are 0.5 to $1.0 \%$ higher than stratigraphically equivalent brachiopods (Suan et al., 2010) sampled from the same site (Fig. 7). It is thus perhaps safer to compare $\delta^{18} \mathrm{O}$ records obtained on the biogenic calcite of organisms with similar ecology and physiology to avoid such palaeoecological complications. The new $\delta^{18} \mathrm{O}$ brachiopod data from Algeria are still 0.5 to $1.0 \%$ o lower than brachiopod $\delta^{18} \mathrm{O}$ data from Portugal, suggesting a more reasonable difference in temperature of about 2 to $4^{\circ} \mathrm{C}$ between bottom water masses of these two areas.

It is very likely that the recorded spatial changes in $\delta^{18} \mathrm{O}$ values of biogenic carbonates also reflect spatial changes in seawater $\delta^{18} \mathrm{O}$ values, as a result of different hydrological regime between the $\mathrm{N}$ and $\mathrm{S}$ Tethys margins and thus indirectly related changes in seawater salinity. The northern margin of Gondwana was characterized from the Middle-Late Triassic to the Early Jurassic by the development of a number of 
610 basins along the northern margin of the Saharan craton. As the opening of Tethys 611 ocean proceeded and the relative sea level increased, these basins were flooded and 612 turned to be evaporitic (Turner et al., 2001). Lithostratigraphic studies of continental 613 basins in Eastern Algeria (e.g., Berkine Basin; Turner and Sherif, 2007) show a 614 succession of lower Sinemurian-Pliensbachian halite deposits, and lower 615 Pliensbachian-upper Toarcian sulphate/halite deposits. In Morocco, similar evaporitic 616 basins are reported (Van Houten, 1977; Peretsman, 1988). This attests for the extent 617 of evaporitic environments along the North Africa margin in the Lower Jurassic, with a 618 vast assemblage of evaporitic basins (Le Roy and Piqué, 2001; Courel et al., 2003; 619 Turner and Sherif, 2007), where Sabkha-type environments developed (Elmi and 620 Benshilil, 1987). Given the proximity of these evaporitic basins to the study area, any 621 continental water input to the marine environment would have drained these evaporitic 622 basins. According to studies on current Sabkha environments, salinity may vary, 623 according to the seasons, between $50 \%$ and $250 \%$ (Amarouayache et al., 2018). 624 Since $\delta^{18} \mathrm{O}$ would change by about $0.2 \%$ per unit change in salinity (Sharp, 2017), a $6255.0 \%$ fluctuation in salinity would be accompanied by a $1.0 \%$ change in the $\delta^{18} \mathrm{O}$ 626 value in the ocean shallow-waters (Sharp, 2017). In the case of runoff of these waters 627 into the ocean, a large $\delta^{18} \mathrm{O}$ positive offset would be expected. As we observe, 628 conversely, a negative $\delta^{18} \mathrm{O}$ offset with respect to other Tethys settings, we can 629 exclude the effects related to Sabkha environment runoff. Besides that, brachiopods 630 are known to be intolerant to important salinity changes, which would result from a 631 strong evaporation or from saline lake drainage (Ager, 1967). Higher evaporation at 632 southern latitudes is thus very unlikely to be the main cause of the observed offset of $633 \delta^{18} \mathrm{O}$ values of NW Algeria and the $\delta^{18} \mathrm{O}$ data from NW Europe. We cannot rule out, 634 however, that the isotopic offset between the $\mathrm{N}$ and $\mathrm{S}$ margin of Tethys is somehow 635 mitigated by such differences in evaporation. In the meantime, more intense 636 precipitations, the combined impact of melting ice and the input of freshwaters by river 637 systems should have produced lower $\delta^{18} \mathrm{O}$ values in the northernmost basins (Rosales 638 et al., 2004b; Dera and Donnadieu, 2012), which may explain the anomalously low 639 belemnite $\delta^{18} \mathrm{O}$ values in the UK compared to all other belemnites records (Fig. 7).

640 The Pliensbachian-Toarcian record from England (Cleveland Basin) is also singular in 641 that it shows an opposite trend for oxygen isotopes compared to NW Algeria, as well 642 as with respect to other localities (Fig. 7). Indeed, the basal Tenuicostatum Zone is 643 marked in England by a distinct positive shift toward higher values, while a wide 
644 negative shift is recorded in NW Algeria (this work) and in Portugal (Suan et al., 2010).

645 Some authors explain this trend by a deepening of sea-level near the 646 Pliensbachian/Toarcian, which is indeed marked by a supra-regional marine 647 transgression (Hardenbol et al., 1998; Pittet et al., 2014). Due to this sea-level rise, 648 belemnites would have migrated in deeper and cooler waters (Korte and Hesselbo, 649 2011). However, one may ask why the same effect was not recorded by belemnites 650 during the T-OAE interval, which recorded an even more important sea-level rise, while 651 belemnites display a negative excursion that can be interpreted as an evidence for 652 warming. Korte and Hesselbo (2011) and Ullmann et al., (2014) attributed this variable 653 response of belemnite $\delta^{18} \mathrm{O}$ record relative to sea-level changes to bottom water 654 anoxia, which forced belemnites to secrete their calcite rostrum in shallower waters 655 during the T-OAE. Similarly, substantial differences in spatial trends in $\delta^{18} \mathrm{O}$ recorded 656 by belemnite rostra and bivalve shells have been documented for several other 657 intervals, such as during the lower Bajocian, the middle Oxfordian, and Lower 658 Tithonian cooling (Dera et al., 2011), and attributed to metabolic and ecological factors. 659 In this regard, our new record emphasizes differences in life habitats, namely the depth 660 in the water column belemnites thrived, as a crucial parameter to consider. 661 Brachiopods conversely were sessile organisms, generally inhabiting shallow-water 662 depth, making them more susceptible to record temperature fluctuations and changes 663 in evaporation-precipitation budgets than belemnites.

664 In summary, all these observations indicate that the $\delta^{18} \mathrm{O}$ trends in brachiopod shell in 665 NW Algeria reflect mainly temperature fluctuations, and suggest that a latitudinal 666 temperature gradient of around 2 to $4^{\circ} \mathrm{C}$ existed between bottom water masses of the central and southern part of the western Tethys during the Early Jurassic.

668

669

\section{Summary and conclusions}

670

We produced a continuous record of carbon and oxygen stable isotope for Upper

672 Sinemurian-Middle Toarcian successions in NW Algeria based on brachiopod calcite.

673 This fills an important gap in the palaeolatitudinal record of carbon and oxygen stable

674 isotopes, which is essential for our understanding of Jurassic climatic belts. The $\delta^{13} \mathrm{C}$ 675 and $\delta^{18} \mathrm{O}$ excursions documented in NW Algeria confirm the main climate and 676 environmental changes previously documented in the NW Tethys, although slight 677 differences can be seen because of the peculiar paleogeographic context of the 
678 studied area. The negative $\delta^{13} \mathrm{C}$ excursion near the Sinemurian/Pliensbachian 679 boundary in NW Algeria, previously documented in England and Portugal, is 680 accompanied by a decrease of $\delta^{18} \mathrm{O}$ values, supporting the hypothesis of a 681 greenhouse-forced warming during this interval. The Pliensbachian/Toarcian boundary 682 negative CIE is well marked on the S-Tethys margin and the coeval shift toward lower $683 \delta^{18} \mathrm{O}$ values is also interpreted as reflecting a transient warming. Also, the well-known 684 T-OAE CIE is documented in NW Algeria along with an intense warming phase, as 685 shown by a coeval decrease of $\delta^{18} \mathrm{O}$ values.

686 The new NW Algerian records are also valuable in that they reveal a systematic positive offset of $\sim 0.5 \%$ for $\delta^{13} \mathrm{C}$ values and negative offset of $\sim 1.5 \%$ for $\delta^{18} \mathrm{O}$ values compared to European sections. We interpret these offsets as mainly reflecting higher seawater temperatures along the southern margin of Tethys. This was previously interpreted on the basis of the sedimentary record of widespread carbonate platforms and of evaporitic environments in coastal areas of N-Africa settings. We bring for the first-time quantitative data on the existing temperature gradient. This gradient can further explain the distribution of marine (Bucefalo Palliani and Riding, 2003; Mattioli et al., 2008) or continental organisms (Philippe and Thevenard, 1996), which show significant differences in terms of assemblage composition between the $\mathrm{S}$ and the $\mathrm{N}$ of the Tethys. These new data should be integrated in future climate models to constrain Early Jurassic climate belt distribution and their latitudinal fluctuations during times of environmental perturbations.

699

\section{Acknowledgments}

701

We acknowledge Stéphane Bodin and an anonymous reviewer who provided valuable comments to an early version of the manuscript. We wish to warmly thank Mohammed Adaci, Abbes Sebane, Sid-Ahmed Hammouda, Rachid Sidhoum, Abdelkader Mennad, Ayrton Nadin and Astrid Jonet for their help in fieldwork. Emmanuel Robert is acknowledged for his precious advice and help for fossil selection in the Collections de Géologie de Lyon. Financial support was provided by the Institut Universitaire de France. H.B. was funded by the Eiffel Excellence Scholarship by the French Ministry of Europe and Foreign Affairs, and by the Programme National Exceptionnel "PNE" (Algerian MESRS). This is a contribution of the IGCP 655 (IUGS-UNESCO). 


\section{References}

Aberhan, M., 2001. Bivalve palaeobiogeography and the Hispanic Corridor: Time of opening and effectiveness of a proto-Atlantic seaway. Palaeogeogr. Palaeoclimatol. Palaeoecol. 165, 375-394. https://doi.org/10.1016/S00310182(00)00172-3

Ager, D.V., 1967. Brachiopod palaeoecology. Earth-Science Rev. 3, 157-179. https://doi.org/10.1016/0012-8252(67)90375-3

Ait-Itto, F.Z., Price, G.D., Ait Addi, A., Chafiki, D., Mannani, I., 2017. Bulk-carbonate and belemnite carbon-isotope records across the Pliensbachian-Toarcian boundary on the northern margin of Gondwana (Issouka, Middle Atlas, Morocco). Palaeogeogr.

Palaeoclimatol.

Palaeoecol.

466,

128-136. https://doi.org/10.1016/j.palaeo.2016.11.014

Almeras, Y., Elmi, S., Fauré, P., 2007. Les Brachiopodes Liasiques d'Algérie Occidentale. Docum. Lab. Géol. Lyon, n¹63, 2007, pp. 1-241.

Amarouayache, M., Derbal, F, Kara M. H., 2010. Caractéristiques écologiques et biologiques d'Artemia salina (Crustacé, anostracé) de la Sebkha Ez-Zemoul, Algérie Nord Est. Rev. Écol. (Terre Vie), vol. 65, http://hdl.handle.net/2042/55831

Anderson, T.F. and Arthur, M.A., 1983. Stable isotopes of oxygen and carbon and their application to sedimentologic and paleoenvironmental problems. In: Stable Isotopes in Sedimentary Geology, Society of Economic Paleontology and Mineralogy, Short Course 10, Section 1.1-1.151.

Ameur, M., 1999. Histoire d'une plate-forme carbonatée de la marge Sud-Téthysienne: L'autochtone des Traras (Algérie occidentale) du Trias Supérieur jusqu'au Bathonien Moyen. Docum. Lab. Géol. Lyon, n¹50,1999, pp. 1-399.

Armendáriz, M., Rosales, I., Bádenas, B., Aurell, M., 2012. High-resolution chemostratigraphic records from Lower Pliensbachian belemnites: Palaeoclimatic perturbations, organic facies and water mass exchange (Asturian basin, northern Spain). Palaeogeogr. Palaeoclimatol. Palaeoecol. 333-334, 178-191. https://doi.org/10.1016/j.palaeo.2012.03.029

Auclair, A.C., Joachimski, M.M., Lécuyer, C., 2003. Deciphering kinetic, metabolic and environmental controls on stable isotope fractionations between seawater and the shell of Terebratalia transversa (Brachiopoda). Chem. Geol. 202, 59-78. https://doi.org/10.1016/S0009-2541(03)00233-X 
Bailey, T.R., Rosenthal, Y., McArthur, J.M., van de Schootbrugge, B., Thirlwall, M.F., 2003. Paleoceanographic changes of the Late Pliensbachian-Early Toarcian interval: A possible link to the genesis of an Oceanic Anoxic Event. Earth Planet. Sci. Lett. 212, 307-320. https://doi.org/10.1016/S0012-821X(03)00278-4

Bates, N.R., Brand, U., 1991. Environmental and physiological influences on isotopic and elemental compositions of brachiopod shell calcite: Implications for the isotopic evolution of Paleozoic oceans. Chem. Geol. 94, 67-78. https://doi.org/10.1016/S0009-2541(10)80018-X

Beck, J.W., Edwards, R.L., Ito, E., Taylor, F.W., Recy, J., Rougerie, F., Joannot, P., Henin, C., 1992. Sea-Surface Temperature from Coral Skeletal Strontium/Calcium Ratios. Science 257 (5070), 644 LP-647.

Beerling, D.J., Brentnall, S.J., 2007. Numerical evaluation of mechanisms driving Early Jurassic changes in global carbon cycling. Geology 35, 247-250. https://doi.org/10.1130/G23416A.1

Benhamou, M., 1983. Stratigraphie et milieux de depot du jurassique inferieur et moyen des Beni-Ouarsous et des Beni-Khallad (Massif des Traras, Oranie w). Thèse 3ème cycle, Université d'Oran (unpublished), pp. 1-168.

Benhamou, M., 1996. Évolution tectono-eustatique d'um bassin de la Téthys Maghrebine: I'Ouarsenis (Algérie) pendant le Jurassique Inférieur et Moyen. Thèse Doctorat d'État, Université d'Oran (unpublished), pp. 1-416.

Benhamou, M., Elmi, S., Alméras, Y., 2000. Âge et contexte dynamique des calcaires à brachiopodes téthysiens (Zeilleriidés multiplissés) du Grand pic de l'Ouarsenis(Tell algérien). Comptes Rendus l'Académie des Sci. - Ser. IIA - Earth Planet. Sci. 331, 717-723. https://doi.org/10.1016/S1251-8050(00)01464-6

Bodin, S., Krencker, F.N., Kothe, T., Hoffmann, R., Mattioli, E., Heimhofer, U., Kabiri, L., 2016. Perturbation of the carbon cycle during the late Pliensbachian - early Toarcian: New insight from high-resolution carbon isotope records in Morocco. J. African Earth Sci. 116. https://doi.org/10.1016/j.jafrearsci.2015.12.018

Bodin, S., Mattioli, E., Fröhlich, S., Marshall, J.D., Boutib, L., Lahsini, S., Redfern, J., 2010. Toarcian carbon isotope shifts and nutrient changes from the Northern margin of Gondwana (High Atlas, Morocco, Jurassic): Palaeoenvironmental implications. Palaeogeogr. Palaeoclimatol. Palaeoecol. 297, 377-390. https://doi.org/10.1016/j.palaeo.2010.08.018

Bracène, R., Frizon de Lamotte, D., 2002. The origin of intraplate deformation in the 
Atlas system of western and central Algeria: from Jurassic rifting to Cenozoichttps://doi.org/10.1016/S0040-1951(02)00369-4

783

Brand, U., Veizer, J., 1980. Chemical diagenesis of a multicompnent carbonate system-1: Trace Elements. J. Sedimentol. Petrol. 50, 1219-1236.

Brand, U., Azmy, K., Bitner, M.A., Logan, A., Zuschin, M., Came, R., Ruggiero, E., 2013. Oxygen isotopes and $\mathrm{MgCO}_{3}$ in brachiopod calcite and a new paleotemperature equation. Chem. Geol. 359, 23-31. https://doi.org/10.1016/J.CHEMGEO.2013.09.014

Brand, W. A., Coplen, T.B., Vogl, J., Rosner, M., Prohaska, T., 2014. Assessment of international reference materials for isotope-ratio analysis. Pure and Applied Chemistry 8866, 425-467.

Brand, U., Logan, A., Hiller, N., Richardson, J., 2003. Geochemistry of modern brachiopods: Applications and implications for oceanography and paleoceanography. Chem. Geol. 198, 305-334. https://doi.org/10.1016/S00092541(03)00032-9

Bucefalo Palliani, R., Riding, J.B., 2003. Biostratigraphy, provincialism and evolution of European early Jurassic (Pliensbachian to early Toarcian) dinoflagellate cysts. Palynology 27, 179-214. https://doi.org/10.1080/01916122.2003.9989586

Burdett, J.W., Grotzinger, J.P., Arthur, M.A., 1990. Did major changes in the stableisotope composition of Proterozoic seawater occur. Geology 18, 227-230.

Burgess, S.D., Bowring, S.A., Fleming, T.H., Elliot, D.H., 2015. High-precision geochronology links the Ferrar large igneous province with early-Jurassic ocean anoxia and biotic crisis. Earth Planet. Sci. Lett. 415, 90-99. https://doi.org/10.1016/J.EPSL.2015.01.037

Carpenter, S.J., Lohmann, K.C., 1995. $\delta^{18} \mathrm{O}$ and $\delta^{13} \mathrm{C}$ values of modern brachiopod shells. Geochim. Cosmochim. Acta 59, 3749-3764. https://doi.org/10.1016/00167037(95)00291-7

Clayton, R.N., Degens, E.T., 1959. Use of carbon isotope analyses of carbonates for differentiating fresh-water and marine sediments. Geol. Notes 43, 890-897.

Cleveland, W.S., 1981. LOWESS : A program for smoothing scatterplots by robust locally weighted regression. Am. Stat. 35, 54.

Courel, L., Aït Salem, H., Benaouiss, N., Et-Touhami, M., Fekirine, B., Oujidi, M., Soussi, M., Tourani, A., 2003. Mid-Triassic to Early Liassic clastic/evaporitic 
deposits over the Maghreb Platform. Palaeogeogr. Palaeoclimatol. Palaeoecol. 196, 157-176. https://doi.org/10.1016/S0031-0182(03)00317-1

Curry, G.B., Fallick, A.E., 2002. Use of stable oxygen isotope determinations from brachiopod shells in palaeoenvironmental reconstruction. Palaeogeogr. Palaeoclimatol. Palaeoecol. 182, 133-143. https://doi.org/10.1016/S00310182(01)00456-4

Deocampo, D.M., Jones, B.F., 2014. Geochemistry of Saline Lakes. Treatise on Geochemistry 437-469. https://doi.org/10.1016/B978-0-08-095975-7.00515-5

Dera, G., Donnadieu, Y., 2012. Modeling evidences for global warming, Arctic seawater freshening, and sluggish oceanic circulation during the Early Toarcian anoxic event. Paleoceanography 27, 1-15. https://doi.org/10.1029/2012PA002283

Dera, G., Pellenard, P., Neige, P., Deconinck, J., Pucéat, E., Dommergues, J., 2009. Distribution of clay minerals in Early Jurassic Peritethyan seas : Palaeoclimatic signi fi cance inferred from multiproxy comparisons 271, 39-51. https://doi.org/10.1016/j.palaeo.2008.09.010

Dera, G., Brigaud, B., Monna, F., Laffont, R., Pucéat, E., Deconinck, J., Pellenard, P., Joachimski, M.M., Durlet, C., Dera, G., Brigaud, B., Monna, F., Laffont, R., Pucéat, E., 2011. Climatic ups and downs in a disturbed Jurassic world. https://doi.org/10.1130/G31579.1

Dickens, G.R., O’Neil, J.R., Rea, D.K., Owen, R.M., 1995. Dissociation of oceanic methane hydrate as a cause of the carbon isotope excursion at the end of the Paleocene. Paleoceanography. https://doi.org/10.1029/95PA02087

Dommergues, J.L., Fara, E., Meister, C., 2009. Ammonite diversity and its palaeobiogeographical structure during the early Pliensbachian (Jurassic) in the western Tethys and adjacent areas. Palaeogeogr. Palaeoclimatol. Palaeoecol. 280, 64-77. https://doi.org/10.1016/j.palaeo.2009.06.005

Dromgoole, E.L., Walter, L.M., 1990. Iron and manganese incorporation into calcite: Effects of growth kinetics, temperature and solution chemistry. Chem. Geol. 81, 311-336. https://doi.org/10.1016/0009-2541(90)90053-A

Duarte, L. V, Comas-rengifo, M.J., Silva, R.L., Paredes, R., Goy, A., 2014. Carbon stable isotopes and ammonite biochronostratigraphy across the SinemurianPliensbachian boundary in the Lusitanian Basin , Portugal 16, 2014. https://doi.org/10.3140/bull.geosci.1476 
848 Dutton, A., Huber, B.T., Lohmann, K.C., Zinsmeister, W.J., 2007. High-resolution stable isotope profiles of a dimitobelid belemnite: Implications for paleodepth habitat and late Maastrichtian climate seasonality. Palaios 22, 642-650. https://doi.org/10.2110/palo.2005.p05-064r

Elderfield, H., Ganssen, G.M., 2000. Stable isotope data and calcification temperature from planktic foraminifera in sediment core. Suppl. to Elderfield, H; Ganssen, GM Past Temp. d180 Surf. Ocean waters inferred from Foraminifer. $\mathrm{Mg} / \mathrm{Ca}$ ratios. Nature, $\quad 405(6785), \quad 442-445, \quad$ https//doi.org/10.1038/35013033. https://doi.org/10.1594/PANGAEA.143845

Elmi, S., Almeras, Y., 1984. Physiography, palaeotectonics and palaeoenvironments as controls of changes in ammonite and brachiopod communities (an example from the Early and Middle Jurassic of Western Algeria). Palaeogeogr. Palaeoclimatol. Palaeoecol. 47, 347-360.

Elmi, S., Benshilil, K., 1987. Relations entre la structuration tectonique, la composition des peuplements et l'évolution : exemple du Toarcien du Moyen Atlas méridional (Maroc). Bull. Soc. Paleontol. Ital 26, 47-62.

Elmi, S., Marok, A., Sebane, A., 2006. Importance of the Mellala section (Traras Mountains, northwestern Algeria) for the correlation of the Pliensbachian-Toarcian boundary. Vol. Jurassica VII, 37-45.

Elmi, S., Almeras, Y., Ameur, M., Benhamou, M., 1985. Précisions biostratigraphiques et paléoécologiques sur le Lias des environs de Tiffrit (Saïda, Algérie occidentale. Les Cah. l'institut Cathol. Lyon n 14, 15-42.

Epstein, S., Mayeda, T., 1953. Variation of $\mathrm{O}^{18}$ content of waters from natural sources. Geochim. Cosmochim. Acta 4, 213-224. https://doi.org/10.1016/00167037(53)90051-9

Epstein, S., Buchsbaum, R., Lowenstam, H.A., Urey, H.C., 1953. Revised carbonatewater isotopic temperature scale. GSA Bull. 64, 1315-1326.

Favre, P., Stampfli, G.M., 1992. From rifting to passive margin: the examples of the Red Sea, Central Atlantic and Alpine Tethys. Tectonophysics 215, 69-97. https://doi.org/10.1016/0040-1951(92)90075-H

Faber, N.M., Rajko, R., 2007. How to avoid over-fitting in multivariate calibration-The conventional validation approach and an alternative. Analytical Chimica Acta. 595, 98-106. https://doi.org/10.1016/j.aca.2007.05.030

Franceschi, M., Dal Corso, J., Posenato, R., Roghi, G., Masetti, D., Jenkyns, H.C., 
882

883

884

885

886

887

888

889

890

891

892

893

894

895

896

897

898

899

900

901

902

903

904

905

906

907

908

909

910

911

912

913

914

915

2014. Early Pliensbachian (Early Jurassic) C-isotope perturbation and the diffusion of the Lithiotis Fauna: Insights from the western Tethys. Palaeogeogr.

Palaeoclimatol. Palaeoecol. 410,

255-263. https://doi.org/10.1016/j.palaeo.2014.05.025

Freitas, P., Clarke, L.J., Kennedy, H., Richardson, C., Abrantes, F., 2005. Mg/Ca, $\mathrm{Sr} / \mathrm{Ca}$, and stable-isotope $(\delta 180$ and $\delta 13 \mathrm{C})$ ratio profiles from the fan mussel Pinna nobilis: Seasonal records and temperature relationships. Geochemistry, Geophys. Geosystems. https://doi.org/10.1029/2004GC000872

Giraud, F., Mattioli, E., López-Otálvaro, G.E., Lécuyer, C., Suchéras-marx, B., Alméras, Y., Martineau, F., Arnaud-Godet, F., de Kænel, E., 2016. Marine Micropaleontology Deciphering processes controlling mid-Jurassic coccolith turnover. Mar. Micropaleontol. 125, 36-50. https://doi.org/10.1016/j.marmicro.2016.03.001

Gómez, J.J., Comas-Rengifo, M.J., Goy, A., 2016. Palaeoclimatic oscillations in the Pliensbachian (Early Jurassic) of the Asturian Basin (Northern Spain). Clim. Past 12, 1199-1214. https://doi.org/10.5194/cp-12-1199-2016

Gómez, J.J., Goy, A., Canales, M.L., 2008. Seawater temperature and carbon isotope variations in belemnites linked to mass extinction during the Toarcian (Early Jurassic) in Central and Northern Spain. Comparison with other European sections. Palaeogeogr. Palaeoclimatol. Palaeoecol. 258, 28-58. https://doi.org/10.1016/j.palaeo.2007.11.005

Gradstein, F.M., Ogg, J.G., Schmitz, M.D., Ogg, G.M., 2012. The Geologic Time Scale 2012 Editors The Geologic Time Scale 2012.

Guex, J., Morard, A., Bartolini, A., Morettini, E., 2001. Découverte d'une importante lacune stratigraphique à la limite Domérien-Toarcien: Implications paléoocéanographiques. Bull. la Soc. Vaudoise des Sci. Nat. 87, 277-284.

Hammer, Ø., Harper, D.A.T., Ryan, P.D., 2001. PAST: Paleontological Statistics Software Package for Education and Data Analysis. Palaeontol. Electron. 4(1), 19. https://doi.org/10.1016/j.bcp.2008.05.025

Harazim, D.A., Van De Schootbrugge, B., Sorichter, K., Weug, A., Suan, G., Oschmann, W., 2013. Spatial variability of watermass conditions within the European Epicontinental Seaway during the Early Jurassic (Pliensbachian Toarcian). Sedimentology, 60., 359-390. https://doi.org/10.1111/j.13653091.2012.01344.x 
916 Hardenbol, J., Thierry, J., Farley, M.B., Jacquin, T., de Graciansky, P., Vail, P.R., 1998.

917 Mesozoic and Cenozoic sequence chronostratigraphic framework of European 918 basins. de Graciansky, P. et al., Eds., Mesozoic Cenozoic Seq. Stratigr. Eur. Basins, SEPM, Spec. Publ. 60 3-13.

920 Harries, P.J., Little, C.T.S., 1999. The early Toarcian (Early Jurassic) and the 921 Cenomanian-Turonian (Late Cretaceous) mass extinctions: similarities and 922 contrasts. Palaeogeogr., Palaeoclimatol., Palaeoecol. 154, 39-66.

923 Hermoso, M., Pellenard, P., 2014. Continental weathering and climatic changes 924 inferred from clay mineralogy and paired carbon isotopes across the early to middle Toarcian in the Paris Basin. Palaeogeogr. Palaeoclimatol. Palaeoecol. https://doi.org/10.1016/j.palaeo.2014.02.007

Hesselbo, S.P., Gröcke, D.R., Jenkyns, H.C., Bjerrum, C.J., Farrimond, P., Morgans Bell, H.S., Green, O.R., 2000a. Massive dissociation of gas hydrate during a Jurassic oceanic anoxic event. Nature 406, 392-395. https://doi.org/10.1038/35019044

Hesselbo, S.P., Jenkyns, H.C., Duarte, L. V., Oliveira, L.C.V., 2007. Carbon-isotope record of the Early Jurassic (Toarcian) Oceanic Anoxic Event from fossil wood and marine carbonate (Lusitanian Basin, Portugal). Earth Planet. Sci. Lett. 253, 455470. https://doi.org/10.1016/J.EPSL.2006.11.009

Hesselbo, S.P., Meister, C., Gröcke, D.R., 2000b. A potential global stratotype for the Sinemurian-Pliensbachian boundary (Lower Jurassic), Robin Hood's Bay, UK: Ammonite faunas and isotope stratigraphy. Geol. Mag. 137, 601-607. https://doi.org/10.1017/S0016756800004672

Higgins, J.A., Schrag, D.P., 2006. Beyond methane: Towards a theory for the Paleocene-Eocene Thermal Maximum. Earth Planet. Sci. Lett. https://doi.org/10.1016/j.epsl.2006.03.009

Jenkyns, H.C., 1988. The early Toarcian (Jurassic) event: stratigraphy, sedimentary, and geochemical evidence. Am. J. Sci. 288, 101-151. DOI: 10.2475/ajs.288.2.101

Jenkyns, H.C., Clayton, C.J., 1986. Black shales and carbon isotopes in pelagic sediments from the Tethyan Lower Jurassic. Sedimentology 33, 87-106. https://doi.org/10.1111/j.1365-3091.1986.tb00746.x

Jenkyns, H.C., Clayton, C.J., 1997. Lower Jurassic epicontinental carbonates and mudstones from England and Wales: chemostratigraphic signals and the early 
950

951

952

953

954

955

956

957

958

959

960

961

962

963

964

965

966

967

968

969

970

971

972

973

974

975

976

977

978

979

980

981

982

983

Toarcian anoxic event. Sedimentology 44, 687-706 https://doi.org/10.1046/j.13653091.1997.d01-43.x

Jenkyns, H.C., Jones, C.E., Grocke, D.R., Hesselbo, S.P., Parkinson, D.N., 2002. Chemostratigraphy of the Jurassic System: applications, limitations and implications for palaeoceanography. J. Geol. Soc. 159, 4, pp. 351-378. https://doi.org/10.1144/0016-764901-130

Jones, C.E., Jenkyns, H.C., 2001. Seawater strontium isotopes, oceanic anoxic events, and seafloor hydrothermal activity in the Jurassic and Cretaceous. Am J Sci 112-149. https://doi.org/10.2475/ajs.301.2.112

Jourdan, F., Féraud, G., Bertrand, H., Watkeys, M.K., Renne, P.R., 2008. The40Ar/39Ar ages of the sill complex of the Karoo large igneous province: Implications for the Pliensbachian-Toarcian climate change. Geochemistry, Geophys. Geosystems 9. https://doi.org/10.1029/2008GC001994

Kemp, D.B., Coe, A.L., Cohen, A.S., Schwark, L., 2005. Astronomical pacing of methane release in the Early Jurassic period. Nature 437, 396-399. https://doi.org/10.1038/nature04037

Kharroubi B., 1987. Les brachiopodes Liasiques de l'Algérie Occidentale Etude biostratographique, Paléoécologique et Paléontologique. pp. 1-126, Université Lyon1 (Unpublished).

Korte, C., Hesselbo, S.P., 2011. Shallow marine carbon and oxygen isotope and elemental records indicate icehouse-greenhouse cycles during the Early Jurassic 26, 1-18. https://doi.org/10.1029/2011PA002160

Korte, C., Kozur, H.W., Bruckschen, P., Veizer, J., 2003. Strontium isotope evolution of Late Permian and Triassic seawater. Geochim. Cosmochim. Acta 67, 47-62. https://doi.org/10.1016/S0016-7037(02)01035-9

Krencker, F.N., Bodin, S., Hoffmann, R., Suan, G., Mattioli, E., Kabiri, L., Föllmi, K.B., Immenhauser, A., 2014. The middle Toarcian cold snap: Trigger of mass extinction and carbonate factory demise. Glob. Planet. Change 117, 64-78. https://doi.org/10.1016/j.gloplacha.2014.03.008

Kump, L.R., Arthur, M.A., 1999. Interpreting carbon-isotope excursions: carbonates and organic matter. Chem. Geol. 161, 181-198. https://doi.org/10.1016/S00092541(99)00086-8

Le Roy, P., Piqué, A., 2001. Triassic-Liassic western Moroccan synrift basins in relation to the Central Atlantic opening. Mar. Geol. 172, 359-381. 
https://doi.org/10.1016/S0025-3227(00)00130-4

Li, Q., McArthur, J.M., Atkinson, T.C., 2012. Lower Jurassic belemnites as indicators of palaeo-temperature. Palaeogeogr. Palaeoclimatol. Palaeoecol. 315-316, 3845. https://doi.org/10.1016/j.palaeo.2011.11.006

Littler, K., Hesselbo, S.P., Jenkyns, H.C., 2009. A carbon-isotope perturbation at the Pliensbachian - Toarcian boundary : evidence from the Lias Group , NE England. Geol. Mag. 147, 181-192. https://doi.org/10.1017/S0016756809990458

Lowenstam, H.A., 1961. Mineralogy, $\mathrm{O}^{18} / \mathrm{O}^{16}$ Ratios, and Strontium and Magnesium Contents of Recent and Fossil Brachiopods and Their Bearing on the History of the Oceans. J. Geol. 69, 241-260. https://doi.org/10.1086/626740

Macchioni, F., Cecca, F., 2002. Biodiversity and biogeography of middle-late liassic ammonoids: implications for the early Toarcian mass extinction. Geobios 35, 165175. https://doi.org/10.1016/S0016-6995(02)00057-8

Mattioli, E., Pittet, B., Suan, G., Mailliot, S., 2008. Calcareous nannoplankton changes across the early Toarcian oceanic anoxic event in the western Tethys. Paleoceanography 23, 1-17. https://doi.org/10.1029/2007PA001435

Mcarthur, J.M.Y., Donovan, D.T., Thirlwall, M.F., Fouke, B.W., 2000. Strontium isotope profile of the early Toarcian (Jurassic) oceanic anoxic event, the duration of ammonite biozones, and belemnite palaeotemperatures. Earth Planet. Sci. Lett. 179, 269-285. https://doi.org/10.1016/S0012-821X(00)00111-4

McConnaughey, T.A., Burdett, J., Whelan, J.F., Paull, C.K., 1997. Carbon isotopes in biological carbonates: Respiration and photosynthesis. Geochim. Cosmochim. Acta 61, 611-622. https://doi.org/10.1016/S0016-7037(96)00361-4

Mekahli, L., 1988. Le jurassique inferieur et moyen de la partie occidentale du horst de Rhar-Roubane (Tlemcen, Algerie Occidentale) : stratigraphie, sedimentologie et cadre dynamique. Thèse de Magistère, Université d'Oran (Unpublished), pp. 1245

Oliveira, L.C.V., Rodrigues, R., Duarte, L.V., Lemos, V.B., 2006. Avaliação do potencial gerader de petróleo e interpretação paleoambiental com base em biomarcadores e isótopos estáveis de carbono da seção Pliensbaquiano Toarciano inferior (Jurássico Inferior) da região de Peniche (Bacia Lusitânica, Portugal). Bol. Geociencias da Petrobras 14, 207-234. http://hdl.handle.net/10316/20112

Olsen, P.E., 1997. Stratigraphic Record of the Early Mesozoic Breakup of Pangea in 
1018

1019

1020

1021

1022

1023

1024

1025

1026

1027

1028

1029

1030

1031

1032

1033

1034

1035

1036

1037

1038

1039

1040

1041

1042

1043

1044

1045

1046

1047

1048

1049

1050

1051

the Laurasia-Gondwana Rift System. Annu. Rev. Earth Planet. Sci. 25, 337-401. https://doi.org/10.1146/annurev.earth.25.1.337

O'Neil, J.R., Clayton, R. N., Moyeda, T.K., 1969. Oxygen isotope fractionation in bivalent metal carbonates. J. Chem. Phys. 51, 5547--5558.

Pálfy, J., Smith, P.L., 2000. Synchrony between Early Jurassic extinction, oceanic anoxic event, and the Karoo-Ferrar flood basalt volcanism. Geology 28, 747-750. https://doi.org/10.1130/0091-7613(2000)28<747:SBEJEO>2.0.CO;2

Percival, L.M.E., Witt, M.L.I., Mather, T.A., Hermoso, M., Jenkyns, H.C., Hesselbo, S.P., Al-Suwaidi, A.H., Storm, M.S., Xu, W., Ruhl, M., 2015. Globally enhanced mercury deposition during the end-Pliensbachian extinction and Toarcian OAE: A link to the Karoo-Ferrar Large Igneous Province. Earth Planet. Sci. Lett. 428, 267280. https://doi.org/10.1016/J.EPSL.2015.06.064

Percival, L.M.E., Cohen, A.S., Davies, M.K., Dickson, A.J., Hesselbo, S.P., Jenkyns, H.C., Leng, M.J., Mather, T.A., Storm, M.S., Xu, W., 2016. Osmium isotope evidence for two pulses of increased continental weathering linked to Early Jurassic volcanism and climate change. Geology 44, 759-762. https://doi.org/10.1130/G37997.1

Peretsman, G., 1988. Geochemistry of Moroccan evaporites in the setting of the North Atlantic Rift. J. African Earth Sci. (and Middle East) 7, 375-383. https://doi.org/10.1016/0899-5362(88)90082-6

Philippe, M., Thevenard, F., 1996. Distribution and palaeoecology of the Mesozoic wood genus Xenoxylon: Palaeoclimatological implications for the Jurassic of Western Europe. Rev. Palaeobot. Palynol. 91, 353-370. https://doi.org/10.1016/0034-6667(95)00067-4

Pittet, B., Suan, G., Lenoir, F., Duarte, L.V., Mattioli, E., 2014. Carbon isotope evidence for sedimentary discontinuities in the lower Toarcian of the Lusitanian Basin (Portugal): Sea level change at the onset of the Oceanic Anoxic Event. Sediment. Geol. 303, 1-14. https://doi.org/10.1016/j.sedgeo.2014.01.001

Price, G.D., 1999. The evidence and implications of polar ice during the Mesozoic. Earth-Science Rev. 48, 183-210. https://doi.org/10.1016/S0012-8252(99)000483

Price, G.D., Baker, S.J., VanDeVelde, J., Clémence, M.-E., 2016. High-resolution carbon cycle and seawater temperature evolution during the Early Jurassic (Sinemurian-Early Pliensbachian). Geochemistry, Geophys. Geosystems 17, 
3917-3928. https://doi.org/10.1002/2016GC006541

Reolid, M., Rodríguez-tovar, F.J., Marok, A., Sebane, A., 2012. The Toarcian oceanic anoxic event in the Western Saharan Atlas, Algeria (North African paleomargin): Role of anoxia and productivity 1646-1664. https://doi.org/10.1130/B30585.1

Rosales, I., Quesada, S., Robles, S., 2004a. Paleotemperature variations of Early Jurassic seawater recorded in geochemical trends of belemnites from the BasqueCantabrian basin, northern Spain. Palaeogeogr. Palaeoclimatol. Palaeoecol. 203, 253-275. https://doi.org/10.1016/S0031-0182(03)00686-2

Rosales, I., Quesada, S., Robles, S., 2006. Geochemical arguments for identifying second-order sea-level changes in hemipelagic carbonate ramp deposits. Terra Nov. 18, 233-240. https://doi.org/10.1111/j.1365-3121.2006.00684.x

Rosales, I., Robles, S., Quesada, S., 2004b. Elemental and Oxygen Isotope Composition of Early Jurassic Belemnites: Salinity vs. Temperature Signals. J. Sediment.

Res.

74 ,

342-354. https://doi.org/https://doi.org/10.1306/112603740342

Ruebsam, W., Müller, T., Kovács, J., Pálfy, J., Schwark, L., 2018. Environmental response to the early Toarcian carbon cycle and climate perturbations in the northeastern part of the West Tethys shelf. Gondwana Res. 59, 144-158. https://doi.org/10.1016/J.GR.2018.03.013

Ruhl, M., Hesselbo, S.P., Hinnov, L., Jenkyns, H.C., Xu, W., Riding, J.B., Storm, M., Minisini, D., Ullmann, C. V., Leng, M.J., 2016. Astronomical constraints on the duration of the Early Jurassic Pliensbachian Stage and global climatic fluctuations. Earth Planet. Sci. Lett. 455, 149-165. https://doi.org/10.1016/J.EPSL.2016.08.038

Scholle, P.A., Arthur, M.A., 1980. Carbon isotope fluctuations in Cretaceous pelagic limestones: potential stratigraphic and petroleum exploration tool. Am. Assoc. Pet. Geol. Bull. $64 . \quad$ https://doi.org/10.1306/2F91892D-16CE-11D78645000102C1865D

Sharp, Z., 2017. Principles of Stable Isotope Geochemistry, 2nd Edition. https://doi.org/10.5072/FK2GB24S9F

Silva, R.L., Duarte, L. V, Comas-rengifo, M.J., Filho, J.G.M., Azerêdo, A.C., 2011. Update of the carbon and oxygen isotopic records of the Early - Late. Chem. Geol. 283, 177-184. https://doi.org/10.1016/j.chemgeo.2011.01.010

Silva, R.L., Duarte, L. V, 2015. Organic matter production and preservation in the 
1086

1087

1088

1089

1090

1091

1092

1093

1094

1095

1096

1097

1098

1099

1100

1101

1102

1103

1104

1105

1106

1107

1108

1109

1110

1111

1112

1113

1114

1115

1116

1117

1118

1119

Lusitanian Basin ( Portugal ) and Pliensbachian climatic hot snaps. Glob. Planet. Change 131, 24-34. https://doi.org/10.1016/j.gloplacha.2015.05.002

Suan, G., Pittet, B., Bour, I., Mattioli, E., Duarte, L. V., Mailliot, S., 2008b. Duration of the Early Toarcian carbon isotope excursion deduced from spectral analysis: Consequence for its possible causes. Earth Planet. Sci. Lett. 267, 666-679. https://doi.org/10.1016/j.epsl.2007.12.017

Suan, G., Mattioli, E., Pittet, B., Lécuyer, C., Suchéras-Marx, B., Duarte, L.V., Philippe, M., Reggiani, L., Martineau, F., 2010. Secular environmental precursors to Early Toarcian (Jurassic) extreme climate changes. Earth Planet. Sci. Lett. 290, 448458. https://doi.org/10.1016/J.EPSL.2009.12.047

Suan, G., Mattioli, E., Pittet, B., Mailliot, S., Lécuyer, C., 2008a. Evidence for major environmental perturbation prior to and during the Toarcian ( Early Jurassic ) oceanic anoxic event from the Lusitanian Basin, Portugal. Paleoceanography 23, 1-14. https://doi.org/10.1029/2007PA001459

Steuber, T., Veizer, J., 2002. Phanerozoic record of plate tectonic control of seawater chemistry and carbonate sedimentation. Geology 30, 1123-1126. https://doi.org/10.1130/0091-7613(2002)030<1123:PROPTC>2.0.CO;2

Svensen, H., Planke, S., Chevallier, L., Malthe-sørenssen, A., 2007. Hydrothermal venting of greenhouse gases triggering Early Jurassic global warming 256, 554566. https://doi.org/10.1016/j.epsl.2007.02.013

Talbot, M.R., 1990. A review of the palaeohydrological interpretation of carbon and oxygen isotopic ratios in primary lacustrine carbonates. Chem. Geol. Isot. Geosci. Sect. 80, 261-279. https://doi.org/10.1016/0168-9622(90)90009-2

Thierry, J. et al., 2000. Middle Toarcian. In: Dercourt, J., Gaetani, M., Vrielynck, B., Barrier, E., Biju-Duval, B., Brunet, M.-F., Cadet, J.P., Crasquin, S., Sandulescu, M. (Eds.), Atlas Peri-Tethys Paleogeographical Maps, vol. I-XX.CCGM/CGMW, Paris, map 8, (40 co-authors).

Turner, P., Pilling, D., Walker, D., Exton, J., Binnie, J., Sabaou, N., 2001. Sequence stratigraphy and sedimentology of the late Triassic TAG-I (Blocks 401/402, Berkine Basin, Algeria). Mar. Pet. Geol. 18, 959-981. https://doi.org/10.1016/S0264-8172(01)00039-3

Turner, P., Sherif, H., 2007. A giant Late Triassic Early Jurassic evaporitic basin on the Saharan Platform, North Africa. Geol. Soc. London, Spec. Publ. 285 285, 87-105. https://doi.org/10.1144/SP285.6 
1120 Ullmann, C. V., Campbell, H.J., Frei, R., Korte, C., 2016. Oxygen and carbon isotope and $\mathrm{Sr} / \mathrm{Ca}$ signatures of high-latitude Permian to Jurassic calcite fossils from New Zealand and New Caledonia. Gondwana Res. 38, 60-73. https://doi.org/10.1016/J.GR.2015.10.010

Ullmann, C.V., Thibault, N., Ruhl, M., Hesselbo, S.P., Korte, C., 2014. Effect of a Jurassic oceanic anoxic event on belemnite ecology and evolution. Proc. Natl. Acad. Sci. U. S. A. 16-19. https://doi.org/10.1073/pnas.1320156111

Van de Schootbrugge, B., Bailey, T.R., Rosenthal, Y., Katz, M.E., Wright, J.D., Miller, K.G., Feist-Burkhardt, S., Falkowski, P.G., 2005. Early Jurassic climate change and the radiation of organic-walled phytoplankton in the Tethys Ocean. Paleobiology 31, 73-97. https://doi.org/10.1666/00948373(2005)031<0073:EJCCAT>2.0.CO;2

Van Houten, F.B., 1977. Triassic-Liassic Deposits of Morocco and Eastern North America: Comparison, AAPG Bulletin. https://doi.org/10.1306/C1EA3BFE-16C911D7-8645000102C1865D

Vander Putten, E., Dehairs, F., Keppens, E., Baeyens, W., 2000. High resolution distribution of trace elements in the calcite shell layer of modern Mytilus edulis: Environmental and biological controls. Geochim. Cosmochim. Acta 64, 997-1011. https://doi.org/10.1016/S0016-7037(99)00380-4

Veizer, J., Ala, D., Azmy, K., Bruckschen, P., Buhl, D., Bruhn, F., Carden, G.A.F., Diener, A., Ebneth, S., Godderis, Y., Jasper, T., Korte, C., Pawellek, F., Podlaha, O.G., Strauss, H., 1999. 87Sr/86Sr, $\delta 13 \mathrm{C}$ and $\delta 180$ evolution of Phanerozoic seawater. Chem. Geol. 161, 59-88. https://doi.org/10.1016/S00092541(99)00081-9

Wierzbowski, H., Joachimski, M., 2007. Reconstruction of late Bajocian-Bathonian marine palaeoenvironments using carbon and oxygen isotope ratios of calcareous fossils from the Polish Jura Chain (central Poland). Palaeogeogr. Palaeoclimatol. Palaeoecol. 254, 523-540. https://doi.org/10.1016/j.palaeo.2007.07.010

Wignall, P.B., 2001. Large igneous provinces and mass extinctions. Earth Sci. Rev. 53, 1-33. https://doi.org/10.1016/S0012-8252(00)00037-4

Wildi, W., 1983. La chaîne tello-rifaine (Algérie, Maroc, Tunisie): Structure, stratigraphie et évolution du Trias au Miocène. Rev. Géogr. Phys. Géol. Dyn. 24, 201-297.

Xu, W., Ruhl, M., Jenkyns, H.C., Hesselbo, S.P., Riding, J.B., Selby, D., Naafs, B.D.A., 
Weijers, J.W.H., Pancost, R.D., Tegelaar, E.W., Idiz, E.F., 2017. Carbon sequestration in an expanded lake system during the Toarcian oceanic anoxic event. Nat. Geosci. 10, 129-134. https://doi.org/10.1038/ngeo2871

Legend of figures

Fig. 1. A. Location of Western Algeria in the frame of an Early Jurassic palaeogeographic map (modified after Thierry et al., 2000). The main current circulation pattern is reported, as well as the main climatic modes (i.e., arid and wet) for the Northern and Southern Tethys margin, respectively (after Dera and Donnadieu, 2012). B. Palaeogeographical map of western Algeria during the Toarcian (modified after Elmi and Benshili, 1987).

Fig. 2. Scanning electron micrographs showing the ultra-structures of brachiopod shells $(A$ and

C) Cuersithyris provincialis;

(B) Lobothyris hispanica; Soaresirhynchia tamazirta.

Fig. 3. The relationships between $\delta^{18} \mathrm{O}$ values and $\mathrm{Mn}$, Sr concentrations in brachiopod shells. The arrows indicate the shift produced by diagenetic incorporation in Mn and Sr in brachiopod calcite.

Fig. 4. Cross Plot of $\delta^{13} \mathrm{C}$ versus $\delta^{18} \mathrm{O}$ values of brachiopod shell calcite. Coloured dots represent the different studied localities. The dashed circle corresponds to the $95 \%$ concentration of data points.

Fig. 5. $\mathrm{C}$ and $\mathrm{O}$ isotope compositions of brachiopod calcite from the Upper Sinemurian

1180 to the Middle Toarcian in north-western Algeria. Numerical ages are derived from "The

1181 Geologic Time Scale 2012" (Gradstein et al., 2012). The relative stratigraphic position 1182 of brachiopods in the different sections was respected and vertical bars on the isotope 1183 curves indicate the stratigraphic extension of brachiopod ages according to ammonite zones and sub-zones. The colours of the symbols correspond to the region where the samples come from. A LOESS Smoothing with a 0.1 factor was applied using Past 
1186 3.18. Square symbols show samples recording anomalous $\mathrm{Sr}$ or $\mathrm{Mn}$ contents and 1187 therefore not considered for the LOESS smoothing.

1188 Fig. 6. C-isotope comparisons and chemo-stratigraphy correlation between sections 1189 studied in Algeria: Traras, Rhar Roubane, Ouarsenis, Saïda, and Nador Mountains 1190 (this work); in England: Cleveland Basin (Hesselbo et al., 2000b; Mcarthur et al., 2000; 1191 Jenkyns et al., 2002; Bailey et al., 2003; Korte and Hesselbo, 2011; Li et al., 2012); in 1192 France: Grands Causses Basin, Sud-Est Basin and Paris Basin (Dera et al., 2011; 1193 Harazim et al., 2013); in Spain: Iberian Range, Asturias, and Basque-Cantabrian Basin 1194 (Rosales et al., 2004a; Schootbrugge et al., 2005; Gómez et al., 2008; Armendáriz et 1195 al., 2012); in Portugal: Lusitanian Basin (Jenkyns et al., 2002; Suan et al., 2010). All of 1196 the data have been measured on belemnite calcite, except in Portugal (Suan et al., 1197 2010) and in NW Algeria (this work) where C isotopes have been measured on 1198 brachiopod calcite. Light red and blue shaded areas respectively indicate warming and 1199 cooling events.

Fig. 7. O-isotope comparisons and chemo-stratigraphy correlation between sections studied in Algeria: Traras, Rhar Roubane, Ouarsenis, Saïda, and Nador Mountains (this work); in England: Cleveland Basin (Hesselbo et al., 2000b; Mcarthur et al., 2000; Jenkyns et al., 2002; Bailey et al., 2003; Korte and Hesselbo, 2011; Li et al., 2012); in France: Grands Causses Basin, Sud-Est Basin and Paris Basin (Dera et al., 2011; Harazim et al., 2013); in Spain: Iberian Range, Asturias, and Basque-Cantabrian Basin (Rosales et al., 2004a; Schootbrugge et al., 2005; Gómez et al., 2008; Armendáriz et al., 2012); in Portugal: Lusitanian Basin (Jenkyns et al., 2002; Suan et al., 2010). All of the data have been measured on belemnite calcite, except in Portugal (Suan et al., 2010) and in NW Algeria (this work) where $O$ isotopes have been measured on brachiopod calcite. Light red and blue shaded areas indicate the warming or, conversely, cooling events.

Supplementary data (Appendix A) List of all the brachiopod specimens analysed for carbon and oxygen isotopic composition and strontium and manganese contents. Most of these brachiopods come from Alméras collection (Alméras et al., 2007), which is curated at the Collections de Géologie de Lyon. FSL numbers are provided along with

1218 the section and the locality where they have been collected. Brachiopods from Melalla section were sampled by the authors. A numerical age has been attributed to each 
1220 specimen according to their stratigraphic position and corresponding ammonite 1221 biozonation calibrated against the timescale of Gradstein et al. (2012).

1222

1223 Supplementary data (Appendix B) Synthetic stratigraphic logs with the position of the 1224 brachiopod samples analysed for carbon and oxygen isotope composition. These logs 1225 have been redrawn after Benhamou (1983, 1996); Elmi et al. (1985); Kharroubi (1987); 1226 Mekahli (1988). 


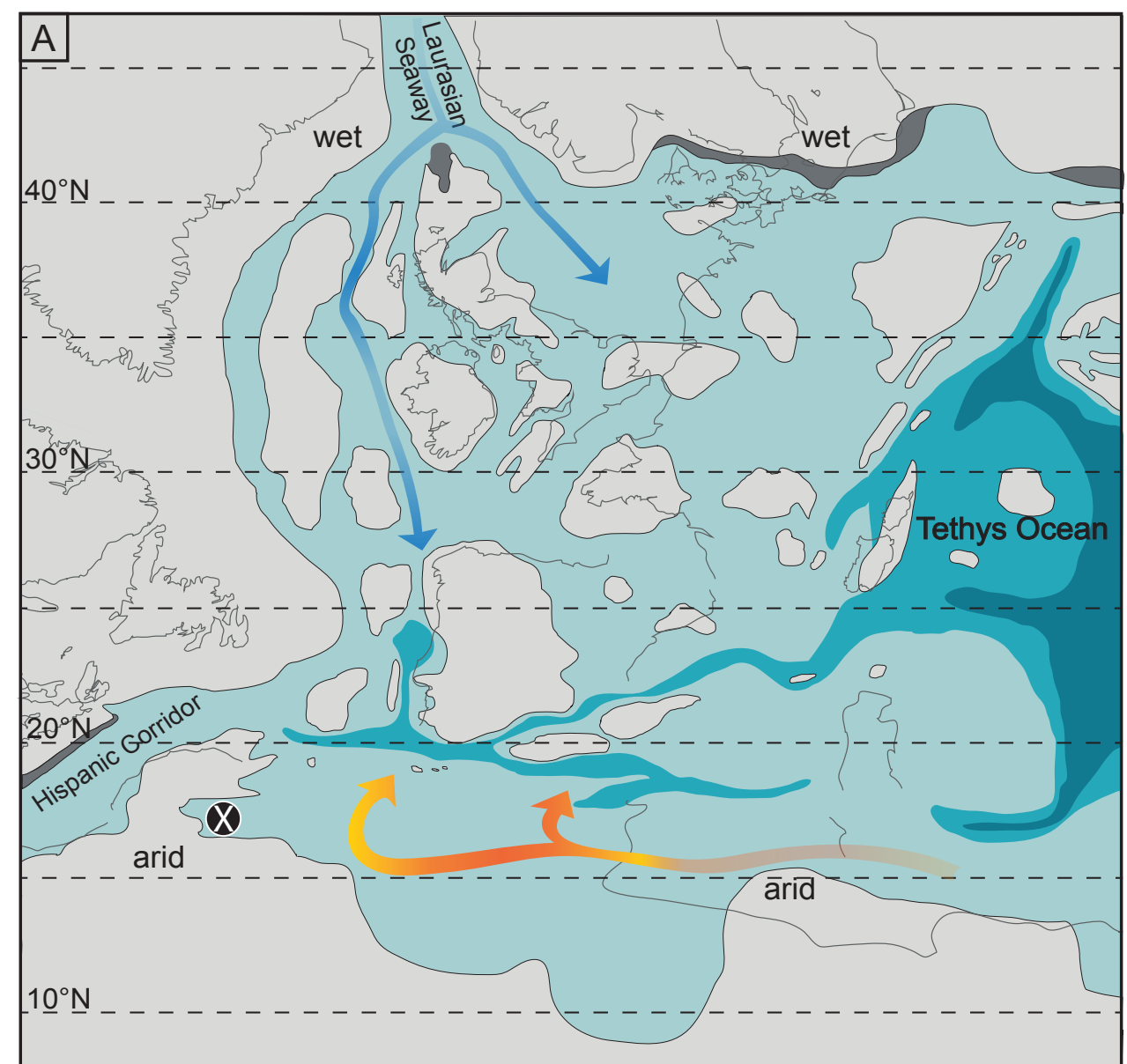

Deep oceanic basin

Deep epicontinental seas

Shallow marine and carbonate platform

Fluviatile, lacustrine

Exposed landmasses
Study area (NW Algeria) low-saline, cool waters high-saline, warm waters

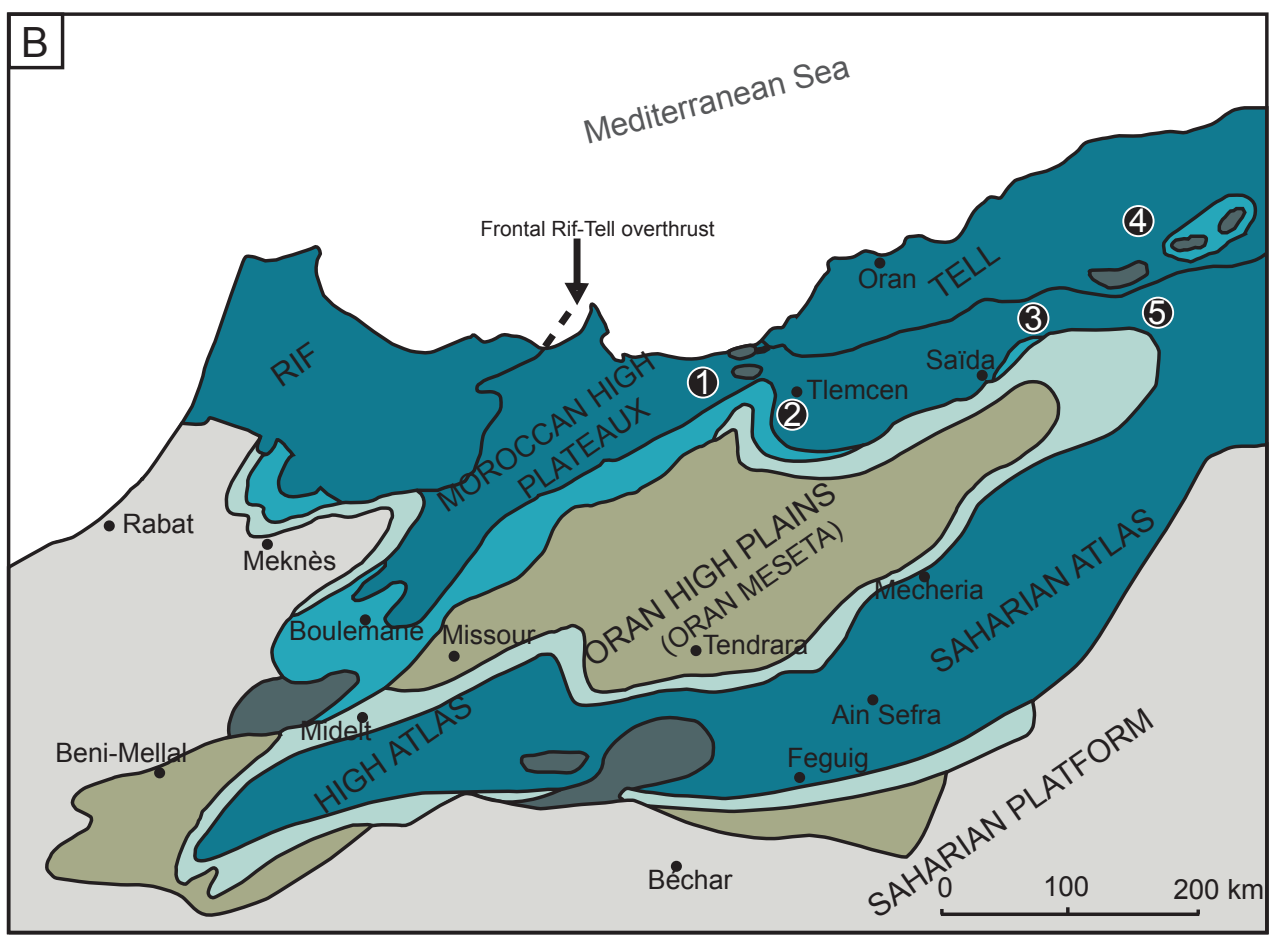

Bassin, gutters and «umbilics»

Outer platforme

Carbonate ramps

Shoals and importants gaps

Sabkha confined facies

Probably emergent areas
(1) Traras Mountains

(2) Rhar Roubane Mountains

(3) Saïda Mountains

(4) Ouarsenis Mountains

(5) Nador Mountains 


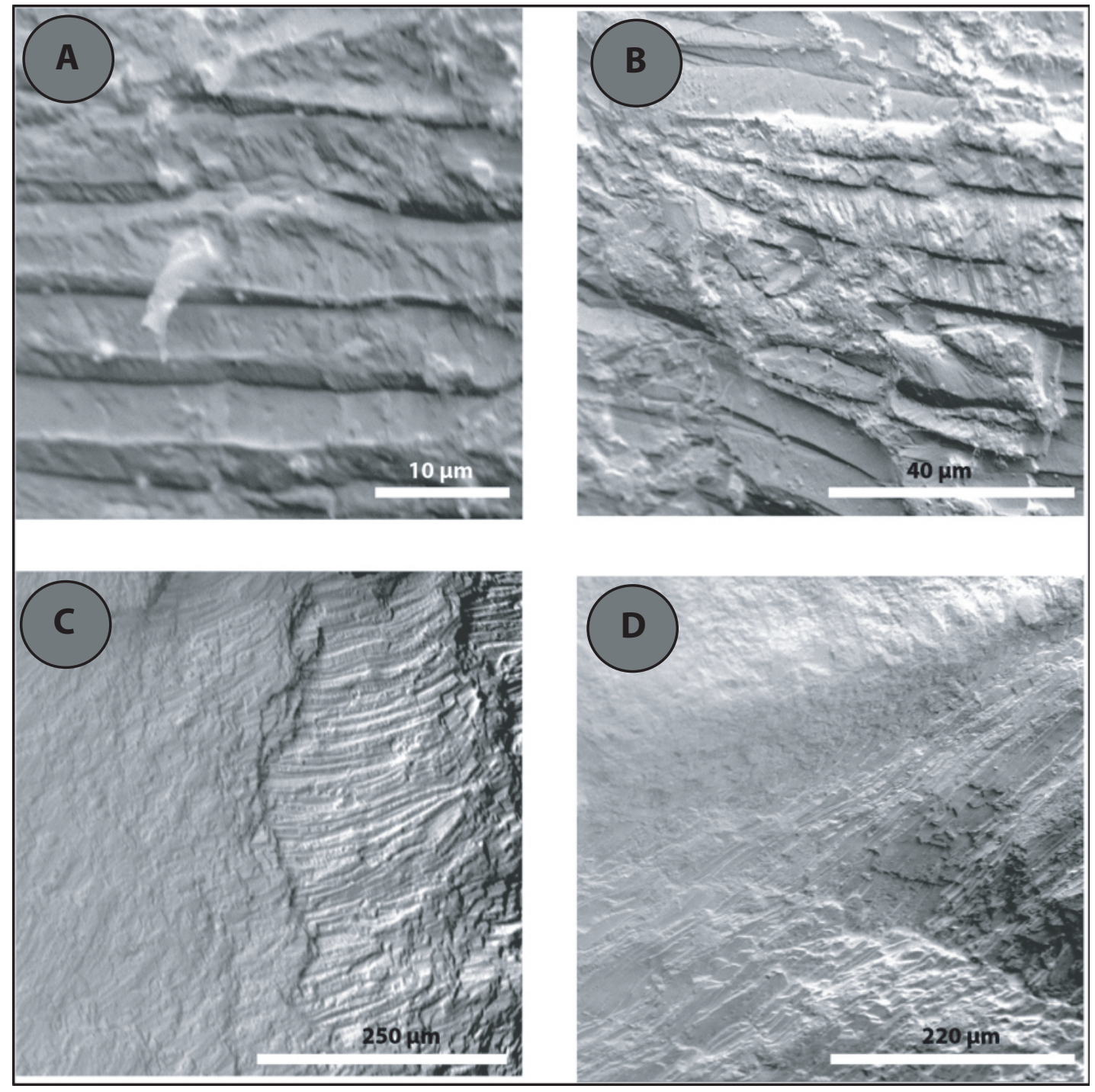

Baghli et al. Figure 2 
- Traras Montains

Rhar Rhoubane Montains

- Saïda Mountains

- Ouarsenis Mountains
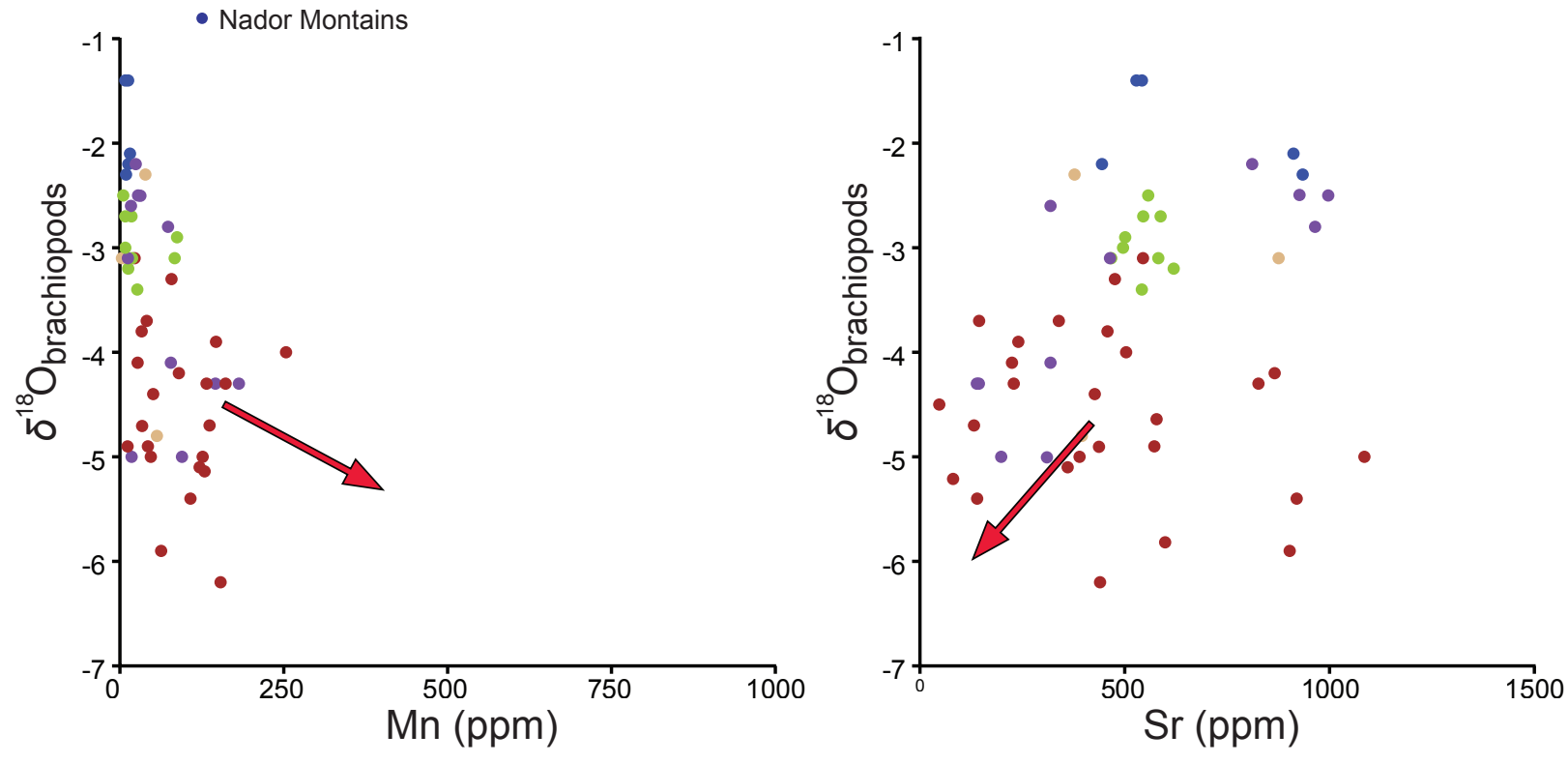

Baghli et al. Figure 3 


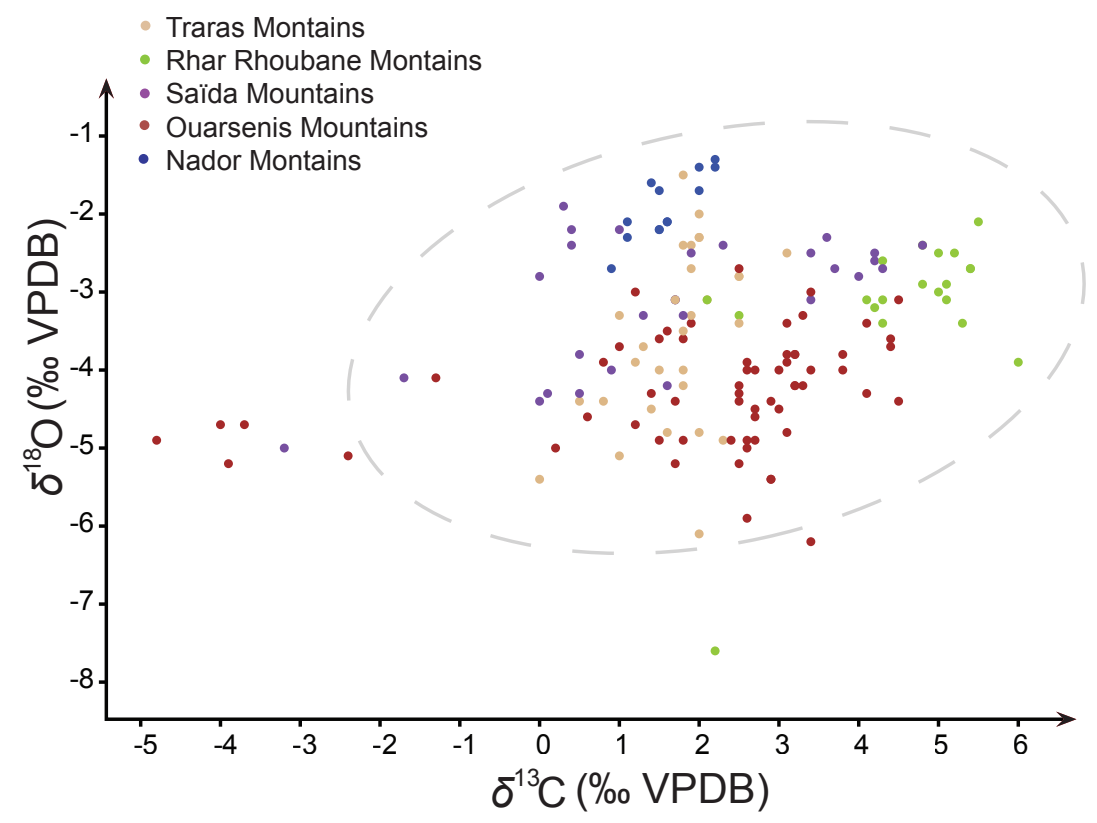

Baghli et al. Figure 4 

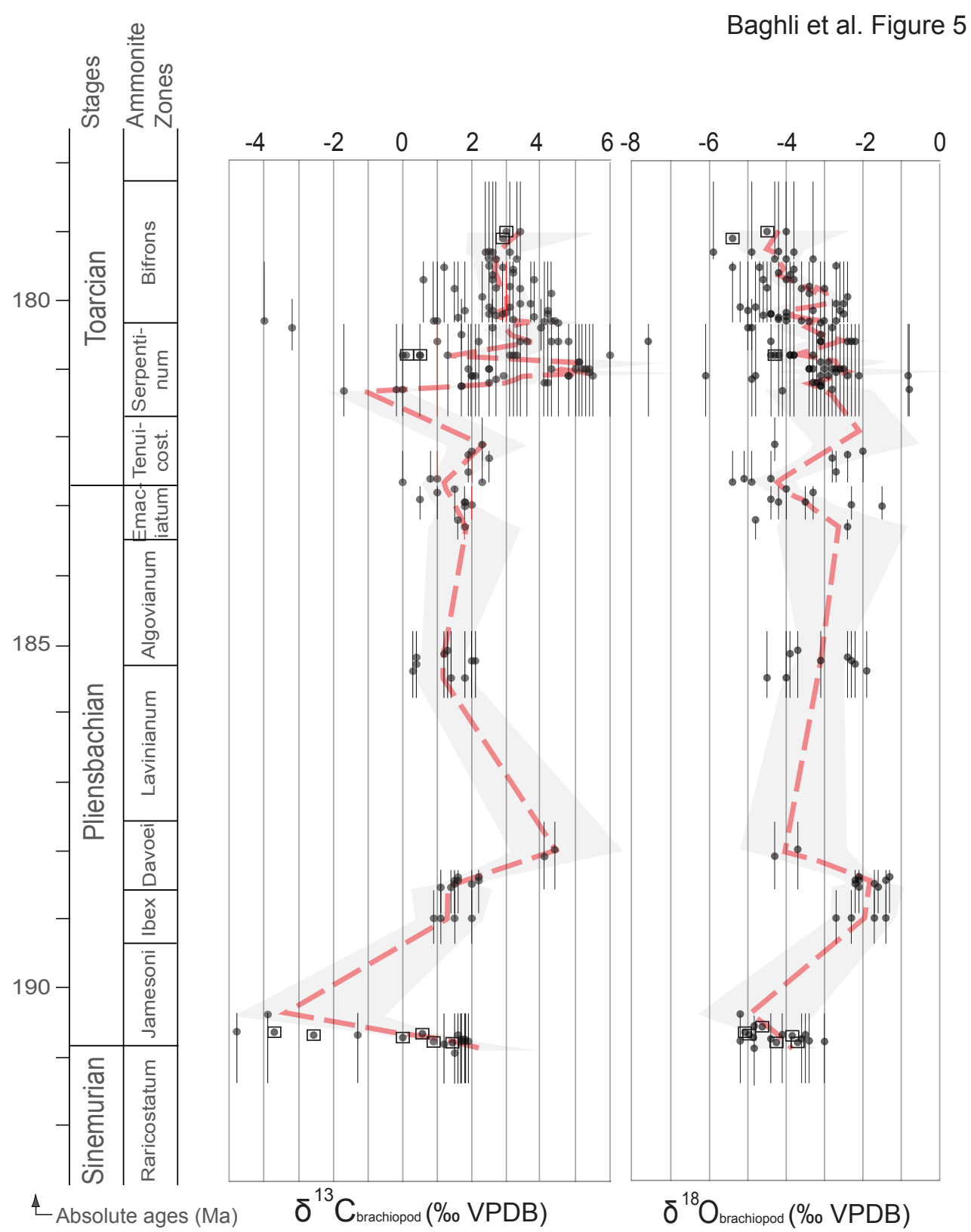

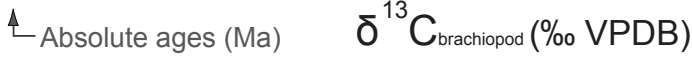
after Gradstein et al., 2012 


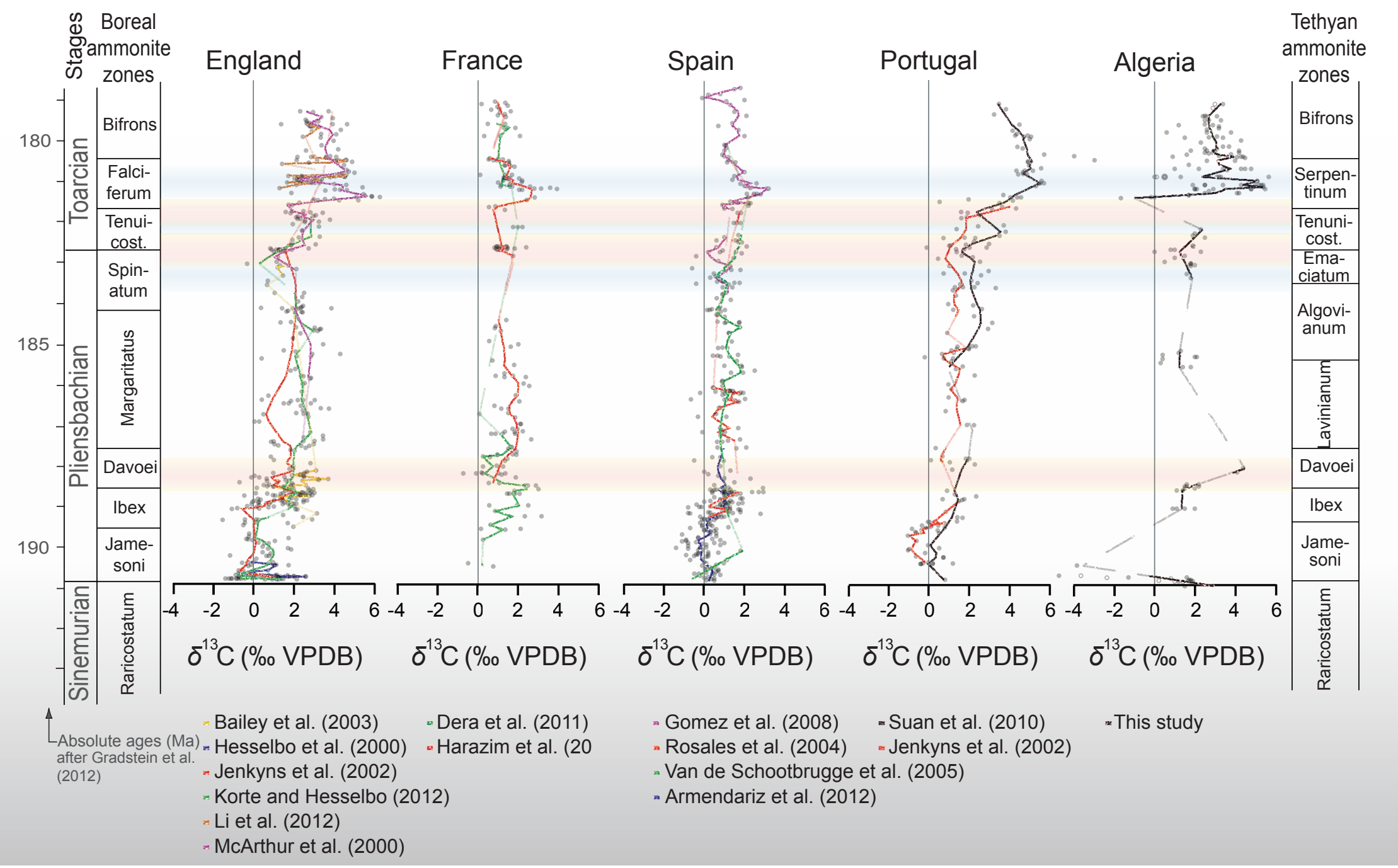

Baghli et al. Figure 6 


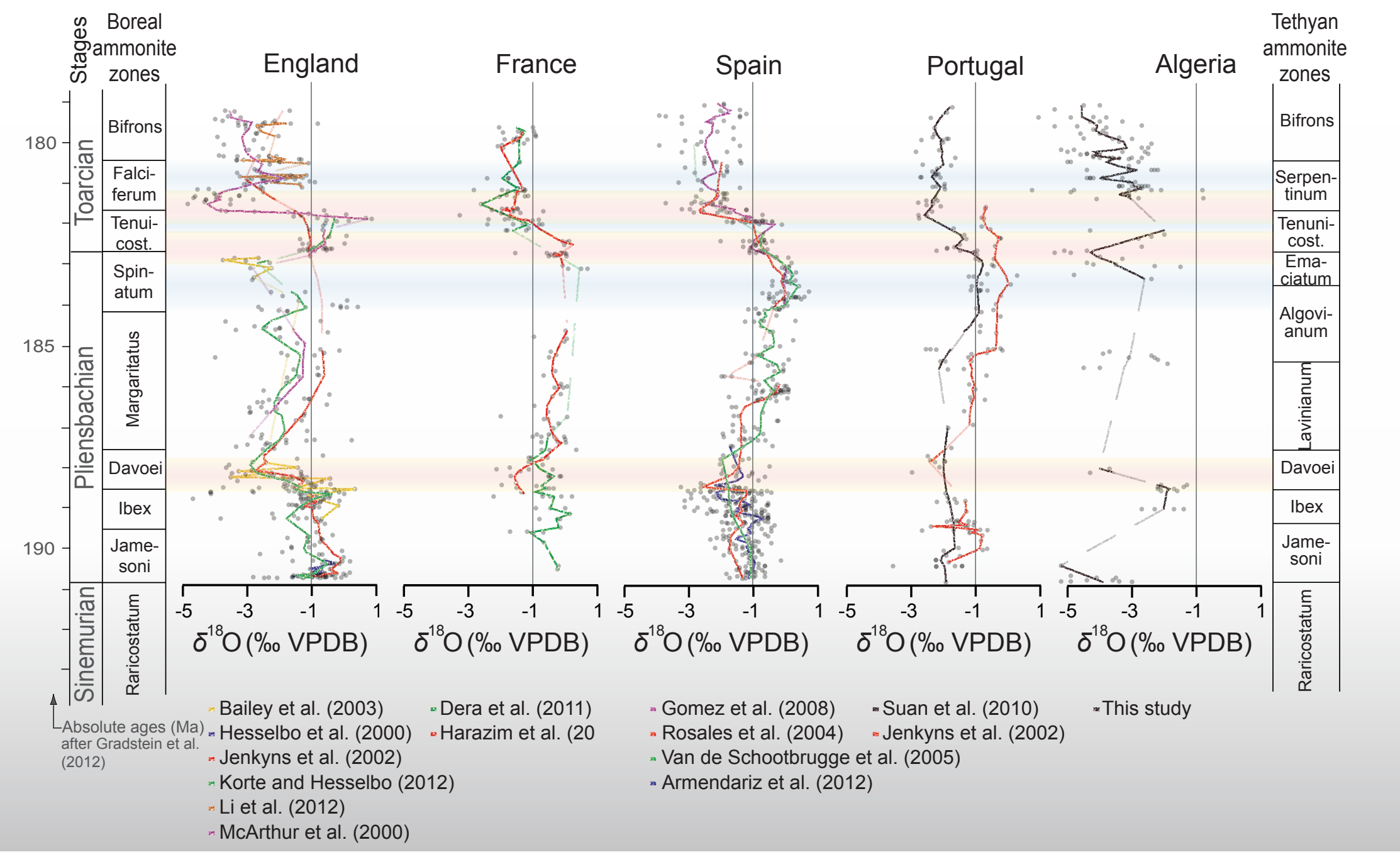




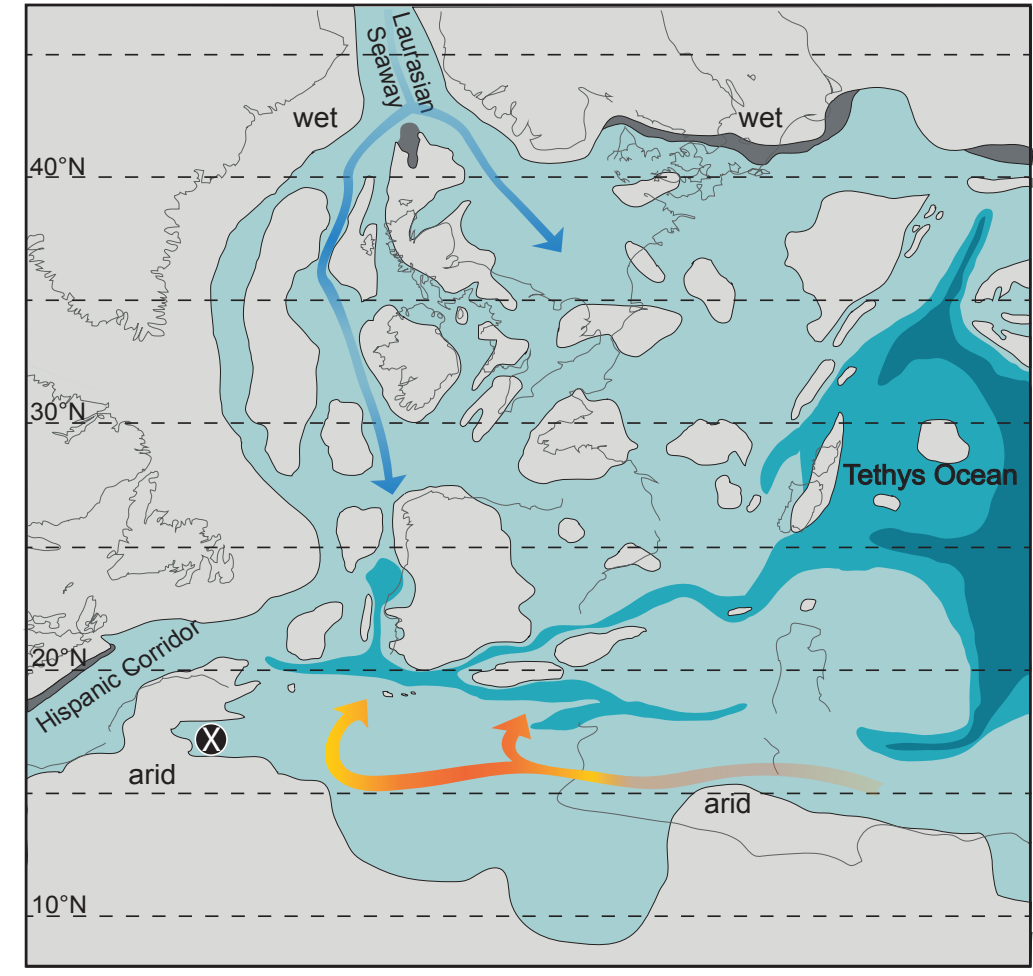

Deep oceanic basin Deep epicontinental seas

Shallow marine and carbonate platform Fluviatile, lacustrine

Exposed landmasses

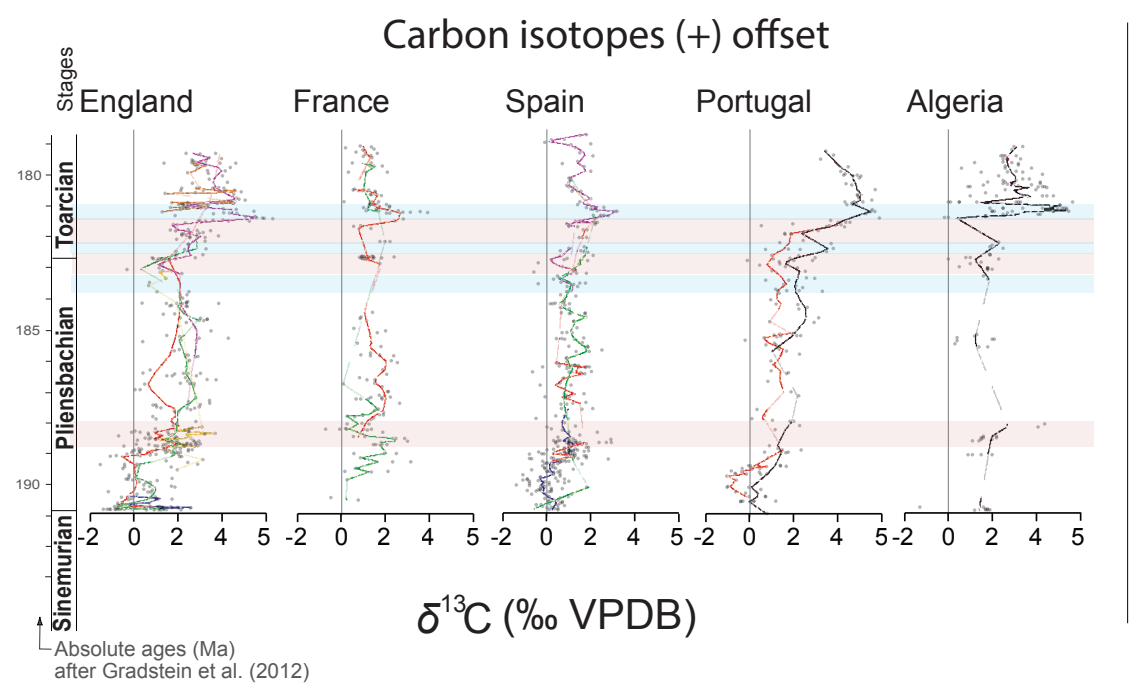

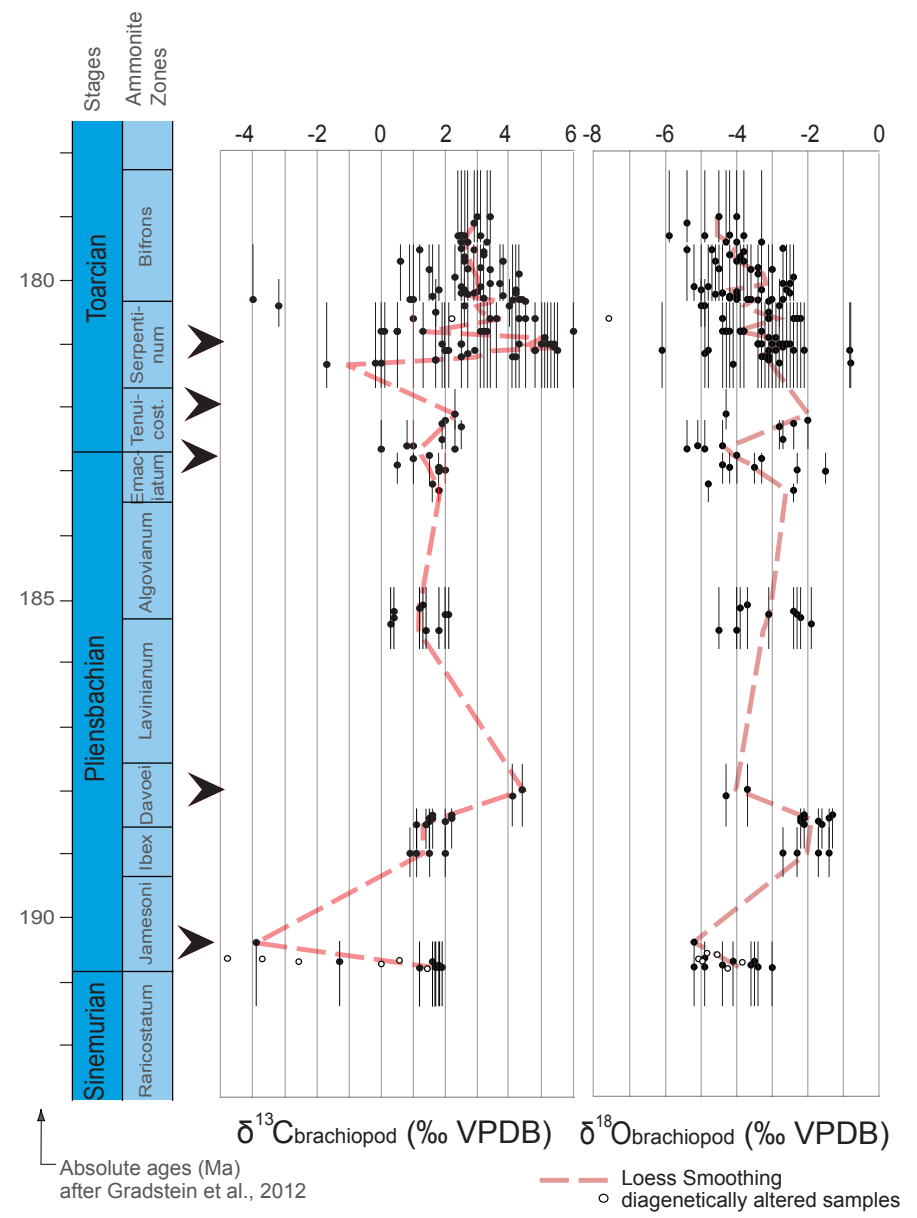

\section{Oxygen isotopes (-) offset}

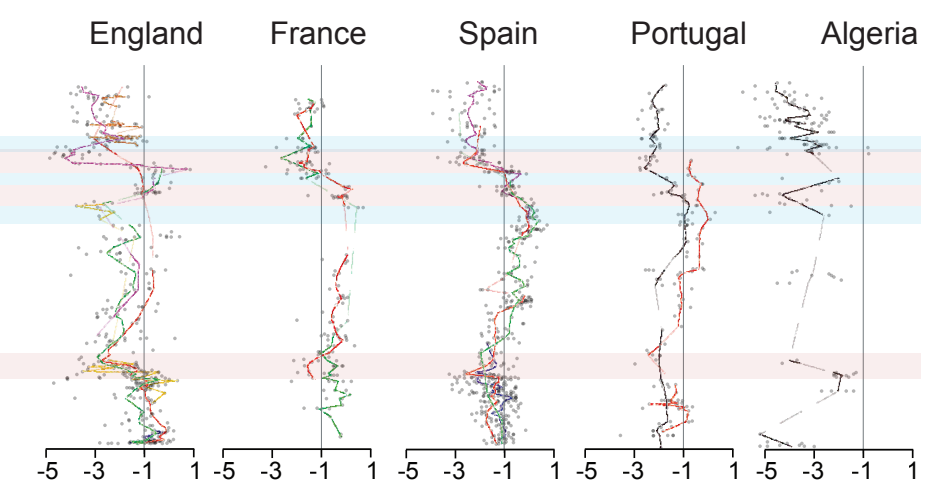

$\delta^{18} \mathrm{O}(\% \mathrm{VPDB})$ 